\title{
Identification of humic-like substances (HULIS) in oxygenated organic aerosols using NMR and AMS factor analyses and liquid chromatographic techniques
}

\author{
M. Paglione ${ }^{1}$, A. Kiendler-Scharr ${ }^{2}$, A. A. Mensah ${ }^{2, *}$, E. Finessi ${ }^{1, * *}$, L. Giulianelli $^{1}$, S. Sandrini ${ }^{1}$, M. C. Facchini ${ }^{1}$, \\ S. Fuzzi ${ }^{1}$, P. Schlag ${ }^{2}$, A. Piazzalunga ${ }^{3}$, E. Tagliavini ${ }^{4}$, J. S. Henzing ${ }^{5}$, and S. Decesari ${ }^{1}$ \\ ${ }^{1}$ National Research Council (CNR), Institute of Atmospheric Sciences and Climate (ISAC), Bologna, Italy \\ ${ }^{2}$ Forschungzentrum Jülich, IEK-8: Troposphere, Jülich, Germany \\ ${ }^{3}$ University of Milano Bicocca, Department of Environmental, and territorial Science and University of Study of Milan, \\ Departement of Chemistry, Milan, Italy \\ ${ }^{4}$ Centro Interdipartimentale di Ricerca per le Scienze Ambientali (CIRSA), University of Bologna, Ravenna, Italy \\ ${ }^{5} \mathrm{TNO}$, Netherlands Applied Research Organisation, Utrecht, the Netherlands \\ *now at: ETH Zurich, Institute for Atmospheric and Climate Science, 8092 Zurich, Switzerland \\ *** now at: University of York, Department of Chemistry, Heslington, York, YO10 5DD, UK
}

Correspondence to: M. Paglione (m.paglione@isac.cnr.it)

Received: 30 April 2013 - Published in Atmos. Chem. Phys. Discuss.: 28 June 2013

Revised: 23 October 2013 - Accepted: 27 November 2013 - Published: 2 January 2014

\begin{abstract}
The atmospheric organic aerosol composition is characterized by a great diversity of functional groups and chemical species, challenging simple classification schemes. Traditional offline chemical methods identify chemical classes based on the retention behaviour on chromatographic columns and absorbing beds. Such an approach led to the isolation of complex mixtures of compounds such as the humiclike substances (HULIS). More recently, online aerosol mass spectrometry (AMS) was employed to identify chemical classes by extracting fragmentation patterns from experimental data series using statistical methods (factor analysis), providing simplified schemes for the classification of oxygenated organic aerosols (OOAs) on the basis of the distribution of oxygen-containing functionalities. The analysis of numerous AMS data sets suggested the occurrence of very oxidized OOAs which were postulated to correspond to HULIS. However, only a few efforts were made to test the correspondence of the AMS classes of OOAs with the traditional classifications from the offline methods. In this paper, we consider a case study representative of polluted continental regional background environments. We examine the AMS factors for OOAs identified by positive matrix factorization (PMF) and compare them to chemical classes of
\end{abstract}

water-soluble organic carbon (WSOC) analysed offline on a set of filters collected in parallel. WSOC fractionation was performed by means of factor analysis applied to proton nuclear magnetic resonance (NMR) spectroscopic data, and by applying an ion-exchange chromatographic method for direct quantification of HULIS. Results show that the very oxidized low-volatility OOAs from AMS correlate with the NMR factor showing HULIS features and also with true "chromatographic" HULIS. On the other hand, UV/VISabsorbing polyacids (or HULIS sensu stricto) isolated on ion-exchange beds were only a fraction of the AMS and NMR organic carbon fractions showing functional groups attributable to highly substituted carboxylic acids, suggesting that unspeciated low-molecular weight organic acids contribute to HULIS in the broad sense.

\section{Introduction}

Atmospheric aerosol particles directly impact air quality, visibility and atmospheric transparency, through scattering and absorption of light (i.e. direct climate forcing effect) and by modulating the formation and properties of clouds 
(i.e. indirect climate forcing effect) which in turn affect the climate system at both regional and global scales (Ghan, 2007; IPCC, 2007; Ravishankara, 2005). Organic Aerosol (OA) constitutes a major fraction (10-90\%) of the submicron $\left(\mathrm{PM}_{1}\right)$ global particulate mass (Kanakidou et al., 2005; Zhang et al., 2007), whereas the rest of the mass consists of soot, inorganic salts, metals and elements. Whereas the elemental and inorganic fraction of the aerosol mass has been quite well described, the composition of the organic fraction is still poorly characterized due to analytical challenges arising from the fact that atmospheric OA (organic aerosols) is a complex mixture of thousands of organic compounds with a great variety of different properties, such as oxidation state, volatility and hygroscopicity, and extremely diverse sources and atmospheric reactions. For this reason, the current knowledge of the sources and source-related properties of OA in the atmosphere is still very uncertain (Fuzzi et al., 2006).

A universal technique for atmospheric organic aerosol analysis does not exist. Trade-offs between specificity or resolution and recovery have to be made, providing a certain degree of complementariness between the analytical techniques (Hallquist et al., 2009). For this reason, a comprehensive characterization can be attempted by employing suitable combinations of techniques. This approach, however, involves the problem of treating heterogeneous chemical data sets with a large number of variables - up to $10^{2}-10^{3}$ in the case of mass spectra or high-resolution proton nuclear magnetic resonance (NMR) spectra. In order to reduce the database complexity, algorithms for multivariate statistical analysis and factor analysis are increasingly used for the identification of "hidden" information in the data sets and for explanation of the variability in the chemical records obtained at a given site using a limited number of relevant variables ("receptor modelling", Viana et al., 2008).

Multivariate statistical techniques, overall called factor analyses, such as positive matrix factorization (PMF) (Paatero and Tapper, 1994; Paatero, 1999) and multivariate curve resolution (Terrado et al., 2010) are used to deconvolve a time series of simultaneous measurements into a set of "factors" or "components", representing groupings of chemical species that correlate in time, and their time-dependent concentrations. These factors can then be related to emission sources, chemical composition and/or atmospheric processing, depending on their specific chemical characteristics and on the phenomenology of concentrations. Because receptor models require no a priori knowledge of meteorological conditions or emission inventories, they are ideal for use in locations where emission inventories are poorly characterized or where atmospheric processing plays a major role.

Several publications in the last years have reported factor analysis of OA data from both offline and online measurements. Most consistent results are based on the deconvolution of AMS (aerosol mass spectrometry) spectra and allowed the separation of OA components into a few chem- ical classes: oxygenated OA (OOA), hydrocarbon-like OA (HOA), and sometimes other components such as biomassburning OA (BBOA, Zhang et al., 2011). It has been found that the majority of OA mass is OOA, which can be further deconvolved into a more oxidized component, the lowvolatility OOA (LV-OOA), and a less oxidized component, the semi-volatile OOA (SV-OOA, Ng et al., 2010).

There is strong evidence that most atmospheric OOA is secondary since its concentration is strongly correlated to photochemical activity (Volkamer et al., 2006). Laboratory and field observations and state-of-the-art gas-to-particle partitioning models suggest that atmospheric OOA are a highly dynamic system, tightly coupled to gas-phase oxidation chemistry (Jimenez et al., 2009). Examination of a large AMS data set for Northern Hemisphere environments $(\mathrm{Ng}$ et al. 2010) showed that in spite of the great variability in compositions in near-source areas, OOA tends to converge to highly oxidized LV-OOA at background sites. LV-OOA composition is confined to a relatively narrow range of most characteristic mass fragments; this must be considered the endpoint of OA ageing in the troposphere. Most interestingly, the AMS spectra of most aged OA exhibit a good overlap with those of a standard of humic-like substances (Alfarra et al., 2006).

Atmospheric humic-like substances (HULIS) have been characterized for more than a decade using chemical methods (mainly liquid chromatography and solid-phase extraction), and were observed in atmospheric aerosol samples encompassing marine, soil dust, biomass burning, biogenic, and urban fine aerosols (Baduel et al., 2010; Cavalli et al., 2004; Decesari et al., 2001; Havers et al., 1998; MayolBracero, 2002), representing a major part of the organic fraction. HULIS are involved in several atmospheric processes, including light absorption (Hoffer et al., 2006) and clouddroplet formation (Dinar et al., 2007). Based on seasonal cycles of HULIS concentrations all over Europe, it was hypothesized that the main sources of HULIS are biomass burning in winter, and their secondary formation in summer. Confirmation of this source apportionment scheme is provided by molecular tracer analysis and by changes in the specific light absorbance of HULIS per unit mass of carbon (Baduel et al., 2010). Whereas primary biomass-burning emissions of HULIS are relatively well known (Mayol-Bracero, 2002; Schmidl et al., 2008), secondary pathways leading to their formation and evolution are still poorly characterized. Proposed mechanisms encompass photochemical production in clouds (Noziere et al. 2009) as well as heterogeneous production in the aerosol phase (Limbeck et al., 2003; Reinhardt et al., 2007).

The identification of highly oxidized LV-OOA rich in carboxylic acids by AMS resumed the concept of HULIS and the two terms are now often used synonymously in the literature. On the other hand, AMS spectra which are obtained by a highly destructive electron impact ionization cannot differentiate between light and heavy molecular weight compounds. 
Moreover, solid-phase extraction (SPE) protocols for HULIS associate them with the more hydrophobic fraction of watersoluble aerosols (e.g. Varga et al., 2001), conflicting with the AMS results identifying LV-OOA amongst the most oxygenated (hydrophilic) components of aerosol organic matter (Ng et al., 2010). Clearly, the actual link between AMS LVOOA and SPE HULIS needs to be established on a firmer experimental basis. The very first investigation of this issue was reported in the paper by El Haddad et al. (2012).

Our study discusses the submicron organic particle composition in the rural area of Cabauw, the Netherlands, in springtime 2008. Earlier publications from the Cabauw EUCAARI (European Integrated Project on Aerosol Cloud Climate Air Quality Interactions) intensive observation period (IOP) of May 2008 have focused on the aerosol direct effect (Roelofs et al., 2010; Morgan et al., 2010; Derksen et al., 2011) and the inorganic composition of aerosol based on a comparison between results from different instruments, such as mass spectrometric, monitor for aerosol and Gases (MARGA) and thermal-desorption proton-transfer-reaction mass-spectrometry (TD-PTR-MS) measurements (Mensah et al., 2012). Mensah et al. (2012) also present an overview of key properties of the organic fraction, indicating that OOA dominated over HOA in May 2008 and that the $\mathrm{O} / \mathrm{C}$ ratio had a pronounced daytime maximum. A detailed discussion of the relative importance of functionalization versus fragmentation in the organic aerosol aging in models and its effect on observed overall $\mathrm{O} / \mathrm{C}$ ratios in the organic aerosol fraction is presented in Murphy et al. (2012).

In our study, factor analysis methods were applied to an advanced spectrometric techniques, proton nuclear magnetic resonance (hereafter NMR), in order to characterize the detailed chemistry of the water-soluble organic carbon (WSOC) at the Cabauw site and to resolve and define the principal components of $\mathrm{OA}$ and their possible nature and prevalent sources. Results from this offline analysis were compared with those from PMF applied to online parallel measurements by an Aerodyne High-Resolution Timeof-Flight Aerosol Mass Spectrometer (HR-ToF-AMS, from here on AMS). Factors differentiated by $\mathrm{O} / \mathrm{C}$ ratio or degree of substitution were extracted by factor analysis and oxygenated polysubstituted organic compounds were characterized by both spectroscopic techniques. Furthermore, offline liquid chromatography was used to extract and quantify HULIS with the aim of comparing the results of factor analysis of NMR and AMS data sets.

\section{Experimental methods}

\subsection{Measurement site}

The measurements were conducted at the Cabauw (the Netherlands) measurement station $\left(51^{\circ} 58.223^{\prime} \mathrm{N}\right.$, $\left.4^{\circ} 55.575^{\prime} \mathrm{E}\right)$ in the framework of the EUCAARI field experiment (Kulmala et al., 2009, 2011) which took place in May 2008. The Cabauw Experimental Site for Atmospheric Research (CESAR) observatory is run by the Royal Netherlands Meteorological Institute (KNMI), De Bilt, the Netherlands. The location of the Cabauw site (between the North Sea and the industrialized area of Rotterdam to the west, and the Ruhr region to the east) allow different aerosol types, from polluted to maritime air masses, to be observed. The plain geographical morphology of the Netherlands, especially in the area of Cabauw, reduces ambiguities in terms of air parcel convection and turbulences. The evolution of the general aerosol chemical and optical properties during the EUCAARI May 2008 IOP is discussed by Mensah et al. (2012) and by Aouizerats et al. (2010), respectively.

\subsection{PM $_{1}$ filter measurements}

\subsubsection{Sampling}

Aerosol particles with ambient aerodynamic diameter $<1 \mu \mathrm{m}$ were sampled on pre-washed and pre-baked quartz-fiber filters (Whatman, $9 \mathrm{~cm}$ size) using a dichotomous sampler (Universal Air Sampler, model 310, MSP Corporation) at a constant nominal flow of $300 \mathrm{1} / \mathrm{min}$ located at ground level, next to the CESAR tower. A total of thirty samples were collected between 8 and 26 May. Typically, two filters were sampled every day, with "daytime" (D) $\mathrm{PM}_{1}$ samples collected from $\sim$ 10:00 to $\sim$ 17:00 (local time, UTC+2), and "evening/nighttime" $(N)$ samples collected from $\sim 18: 00$ to $\sim$ 09:00 LT. Exceptionally, long-time integrated samples were also taken (three samples, lasting 35, 40 and $60 \mathrm{~h}$ ). Samples were stored frozen until chemical analysis.

\subsubsection{TC and WSOC analyses}

Total carbon (TC) content was measured directly on small portions of the $\mathrm{PM}_{1}$ filters (about $2 \%$ of sampled area) by evolved gas analysis. Measurements were performed with a Multi N/C 2100 analyser (Analytik Jena, Germany) equipped with a module for solid samples, which are exposed to increasing temperature (up to $950^{\circ} \mathrm{C}$ ) in a pure oxygen carrier gas. Under these conditions all carbonaceous matter (organic, carbonate and elemental carbon) is converted to $\mathrm{CO}_{2}$ (Gelencsér et al., 2000) and TC is measured as total evolved $\mathrm{CO}_{2}$ by a non-dispersive infrared (NDIR) analyser.

The remaining portion of each $\mathrm{PM}_{1}$ filter was extracted with deionized ultra-pure water (Milli-Q) in a sonicating bath for $1 \mathrm{~h}$, and the water extract was filtered on PTFE membranes (pore size: $0.45 \mu \mathrm{m}$ ) in order to remove suspended particles. Aliquots of water extracts were used to determine the water-soluble organic carbon (WSOC) content by the same Multi N/C 2100 total organic carbon analyser (Analytik Jena, Germany) equipped with a module for liquid samples. For each sample, parallel measurements of total soluble carbon and carbonate carbon were carried out. The difference 
between total soluble carbon and carbonate carbon is taken to be WSOC (Rinaldi et al., 2007). The difference between TC and WSOC and carbonate carbon resulted in the carbon not soluble in water (WINC).

\subsubsection{IC analyses}

Concentrations of major inorganic ions $\left(\mathrm{NH}_{4}^{+}, \mathrm{Na}^{+}, \mathrm{K}^{+}\right.$, $\mathrm{Ca}^{2+}, \mathrm{Mg}^{2+}, \mathrm{Cl}^{-}, \mathrm{NO}_{3}^{-}, \mathrm{SO}_{4}^{2-}$ ) and some organic acids (e.g. oxalate) were determined by ion chromatography (IC) using a Dionex ICS-2000 system. Anions were separated on an IonPac AS11 $(2 \times 250 \mathrm{~mm})$ Dionex separation column in which a solution of Potassium Hydroxide $(\mathrm{KOH})$ was used as eluent. The elution method consists of a gradient from $0.1 \mathrm{mM}$ to $38 \mathrm{mM}$, in a $35 \mathrm{~min}$ long run $(0.1 \mathrm{mM}$ for $10 \mathrm{~min}, 5 \mathrm{mM}$ reached at $15 \mathrm{~min}, 10 \mathrm{mM}$ at $20 \mathrm{~min}$ and $38 \mathrm{mM}$ at $35 \mathrm{~min}$ ). Cations were isocratically separated on an IonPac CS16 $(3 \times 250 \mathrm{~mm})$ Dionex separation column, with a $30 \mathrm{mM}$ solution of methanesulfonic acid (MSA) as eluent. Detection limits were of the order of 0.008 and $0.004 \mu \mathrm{g} \mathrm{m}^{-3}$ for each species and for daytime and nighttime samplings, respectively.

\subsubsection{EC/OC analyses}

One punch (area: $1 \mathrm{~cm}^{2}$ ) cut from each quartz fiber filter sample was analysed by the thermal-optical transmittance method (TOT) (Birch and Cary, 1996) using the EUSAAR_2 protocol (Cavalli et al., 2010) to quantify the elemental and organic carbon fractions. The technique detection limit was $0.2 \mu \mathrm{gC} \mathrm{cm}{ }^{-2}$ of filter, corresponding to $0.05 \mu \mathrm{gC} \mathrm{m}^{-3}$ in air for a sampling time of $12 \mathrm{~h}$, and the precision was $\pm 5 \%(\mathrm{Pi}-$ azzalunga et al., 2013; Subramanian et al., 2006). The TC $(=\mathrm{OC}+\mathrm{EC})$ concentrations determined by the TOT analyser show an excellent agreement $(R=0.98$; slope $=0.96)$ with those determined using the Analytik Jena Multi N/C 2100 analyzer.

\subsubsection{NMR analyses}

The remaining aliquots of the water extracts were dried under vacuum and re-dissolved in deuterium oxide $\left(\mathrm{D}_{2} \mathrm{O}\right)$ for functional group characterization by proton nuclear magnetic resonance (H-NMR) spectroscopy (Decesari et al., 2000). The NMR spectra were acquired at $400 \mathrm{MHz}$ with a Varian Mercury 400 spectrometer in $5 \mathrm{~mm}$ probes. Sodium 3trimethylsilyl- $\left(2,2,3,3-\mathrm{d}_{4}\right)$ propionate $\left(\mathrm{TSP}-\mathrm{d}_{4}\right)$ was used as a reference internal standard, adding $50 \mu \mathrm{L}$ of a TSP- $\mathrm{d}_{4} 0.05 \%$ (w/w) solution in $\mathrm{D}_{2} \mathrm{O}\left(1.5 \mu \mathrm{mol} \mathrm{H}\right.$ in a $5 \mathrm{~mm}$ tube). ${ }^{1} \mathrm{H}-$ NMR spectroscopy in protic solvents provides the speciation of hydrogen atoms bound to carbon atoms. On the basis of the range of frequency shifts (the so-called "chemical shift",ppm) in which the signals occur, they can be attributed to $\mathrm{H}-\mathrm{C}$ containing specific functionalities.

\subsubsection{HULIS analysis by high-performance liquid chromatography (HPLC)}

HULIS determination was conducted on a subset of filter extracts $(n=18)$ by the anion-exchange high-performance liquid chromatography (HPLC-TOC) technique described by Mancinelli et al. (2007). The technique, based on a purely inorganic buffer, allows to fractionate WSOC into four broad classes, namely neutral/basic compounds (NB), monoacids (MA), diacids (DA) and polyacids (PA, representative of humic-like substances), and to quantify them by offline TOC analysis. The same Multi N/C 2100 total organic carbon analyser used for total WSOC analysis was also employed for analysis of the chromatographic fractions.

\subsection{High-resolution time-of-flight aerosol mass spectrometry}

As described in detail in Mensah et al., (2012), an Aerodyne High-Resolution Time-of-Flight Aerosol Mass Spectrometer (AMS) was located in the basement of the CESAR tower. A common stainless steel aerosol sampling line of $1.27 \mathrm{~cm}$ outer diameter connected an inlet system at $60 \mathrm{~m}$ height with a manifold in the basement. The total flow sustained in the $60 \mathrm{~m}$ inlet pipe was kept at about $60 \mathrm{~L} \mathrm{~min}^{-1}$, and Nafion dryers at the inlet dried the aerosol stream. The AMS was connected to the sampling manifold by $3 \mathrm{~m}$ stainless steel tubing with an inner diameter of $4 \mathrm{~mm}$. A flow of $680 \mathrm{~mL} \mathrm{~min}^{-1}$ between the manifold and the AMS inlet was achieved by parallel sampling of the AMS $\left(80 \mathrm{~mL} \mathrm{~min}^{-1}\right)$ and an Ultrafine Condensational Particle Counter (UCPC, TSI 3786, $600 \mathrm{~mL} \mathrm{~min}^{-1}$ ).

The AMS allows for the mass spectrometric online investigation of the non-refractory aerosol particle composition. The working principle of the AMS is described in detail in Canagaratna et al. (2007), Jayne et al. (2000), and Jimenez et al. (2003). Therefore, only a brief summary of the modes of operation and calibrations performed during the campaigns follows here. The most important parts of the AMS are an aerodynamic lens as the inlet, a vaporization/ionization region and a high-resolution mass spectrometer (HR-MS). An aerosol stream of $80 \mathrm{~mL} \mathrm{~min}^{-1}$ passes through a Liu-type aerodynamic lens (Liu et al., 1995a, b), which has an almost $100 \%$ transmission efficiency for particles between $60 \mathrm{~nm}$ and $600 \mathrm{~nm}$. Still, substantial transmission of smaller $(30 \mathrm{~nm}$ to $70 \mathrm{~nm})$ and larger $(500 \mathrm{~nm}$ to $2500 \mathrm{~nm})$ particles is achieved (Jayne et al., 2000; Zhang et al., 2004). The particles exit the aerodynamic lens in a narrow beam of approximately $1 \mathrm{~mm}$ and strike against a conic tungsten surface, the vaporizer. The non-refractory components of the particles are flash evaporated at approximately $600^{\circ} \mathrm{C}$ on the surface of the vaporizer and the resulting vapour molecules are ionized by $70 \mathrm{eV}$ electron impact (EI). The ions are then extracted into the HR-ToF, which acquires a full mass spectrum in one ion extraction occurring every $30 \mu \mathrm{s}$. The resolving power of 
about 2000 (DeCarlo et al., 2006) allows for a clear separation of different ions with the same nominal mass, e.g. $\mathrm{C}_{2} \mathrm{H}_{3} \mathrm{O}^{+}$and $\mathrm{C}_{3} \mathrm{H}_{7}^{+}$on mass to charge ratio $\mathrm{m} / z 43$.

The ionization efficiency (IE) was determined with dried and size selected ammonium nitrate particles according to the calibration procedures described in Drewnick et al. (2004) and Jayne et al. (2000). The determination of the collection efficiency (CE, Huffman et al., 2005) took the composition (Mensah et al., 2012) and relative humidity dependence into account. Data was collected with a time resolution of $5 \mathrm{~min}$ utes.

\subsection{Factor analysis of environmental measurements}

Factor analysis involves a wide set of multivariate statistical techniques that were extensively used in atmospheric science in the last decade, aiming for the apportion of aerosol sources on the basis of the internal correlations of observational data collected at a measurement point, called "receptor site" (Viana et al., 2008). Receptor modelling by factor analysis does not need any detailed a prior knowledge of source profiles and it is therefore most useful for determination of aerosol fractions of secondary origin.

Starting with the principal component analysis (PCA), recent developments are designed to be especially applicable to working with environmental data by forcing all the values in the solutions to be non-negative, which is more realistic and meaningful from a physical point of view.

"Positive matrix factorization" (PMF) (Paatero and Tapper, 1994; Paatero, 1999) is by far the most widespread tool for AMS spectral data analysis and in this study it is also applied exploratively to aerosol NMR spectral data. "Nonnegative matrix factorization" (N-NMF) and "multivariate curve resolution" (MCR) comprise the most common NMR spectral unmixing techniques in many chemometric applications (Karakach et al., 2009) and are also applied to the present NMR data set.

Basically, regardless of the specific constraints imposed and of the different algorithms, all the different methods of factor analysis exploited are based on the same bilinear model that can be described by Eq. (1):

$x_{i j}=\sum_{k=1}^{p} g_{i k} f_{k j}+e_{i j}$,

where $x_{i j}$ refers to a particular experimental measurement of concentration species $j$ (one of the analytes or, here, one point of the mass or NMR spectrum) in one particular sample $i$. Individual experimental measurements are decomposed into the sum of $p$ contributions or sources, each one of which is described by the product of two elements; one of these elements, $\left(f_{k j}\right)$, defines the relative amount of the considered variable $j$ in the source composition (loading of this variable on the source) and the other, $\left(g_{i k}\right)$, defines the relative contribution of this source in that sample $i$ (score of the source on this sample). The sum is extended to $k=1, \ldots, p$ sources, leaving the measurement unexplained residual stored in $e_{i j}$.

\subsubsection{Factor analysis of NMR spectra}

The collection of 25 NMR spectra was processed using factor analysis methodologies in order to find contributions and spectral profiles (loadings) of major components of WSOC. Note that the carbon fraction not soluble in water (WINC) was not analysed by NMR in this study and therefore was not accounted for by this factor analysis.

The original NMR spectra were subjected to several preprocessing steps prior to the application of factor analysis in order to remove spurious sources of variability. A polynomial fit was applied to baselines and subtracted from the spectra. Careful horizontal alignment of the spectra was performed using the Tsp-d4 singlet as reference position. Blank signals, corresponding to impurities of quartz filters or $\mathrm{D}_{2} \mathrm{O}$ contaminations (at e.g. 1.25, 1.31 and $1.33 \mathrm{ppm}$ ), were removed. The spectral regions containing only sparse signals $(\delta \mathrm{H}<0.5 \mathrm{ppm} ; 4.7<\delta \mathrm{H}<5.2 \mathrm{ppm}$; and $\delta \mathrm{H}>8.5 \mathrm{ppm})$ were omitted from the data set. Binning over $0.030 \mathrm{ppm}$ of chemical shift intervals was applied to remove the effects of peak position variability caused by matrix effects. Low-resolution (200-point) spectra were finally obtained and processed by factor analysis.

The EPA open-source software EPA-PMF v3.0 was used for PMF analysis. Two different algorithms were used for $\mathrm{N}$ NMF; one employed a projected gradient bound-constrained optimization (Lin, 2007), and the other a multiplicative update approach (Lee and Seung, 2001). MCR was run according to two different algorithms: the classical alternating least-squares approach (MCR-ALS, Jaumot et al., 2005; Tauler 1995) and a weighted alternating least-squares method (MCR-WALS, Wentzell et al., 2006).

Unlike N-NMF and MCR, PMF requires an error matrix as input. Here this was derived here from measures of the baseline noise in the spectra; specifically, a spectral region showing no visible resonances from the sample was identified between 6 and $7 \mathrm{ppm}$ and the noise, calculated as twice the standard deviation of the baseline signal, was used as uncertainty for PMF.

\subsubsection{PMF of AMS-spectra}

The application of PMF analysis to the organic fraction of AMS mass spectra can be used for source apportionment of the organic aerosol, which is an important part of field data interpretation (Aiken et al., 2009; Huffman et al., 2009; Lanz et al., 2007). Details regarding the application of PMF to AMS data can be found in Ulbrich et al. (2009). Basically, the rows of the matrix $\left(x_{i j}\right)$ represent the averaged mass spectra obtained at each single measurement point and the columns represent the time series of the individual $\mathrm{m} / \mathrm{z}$ measured. The rows of the $f_{k j}$ matrix are the factor profiles (mass spectra) 

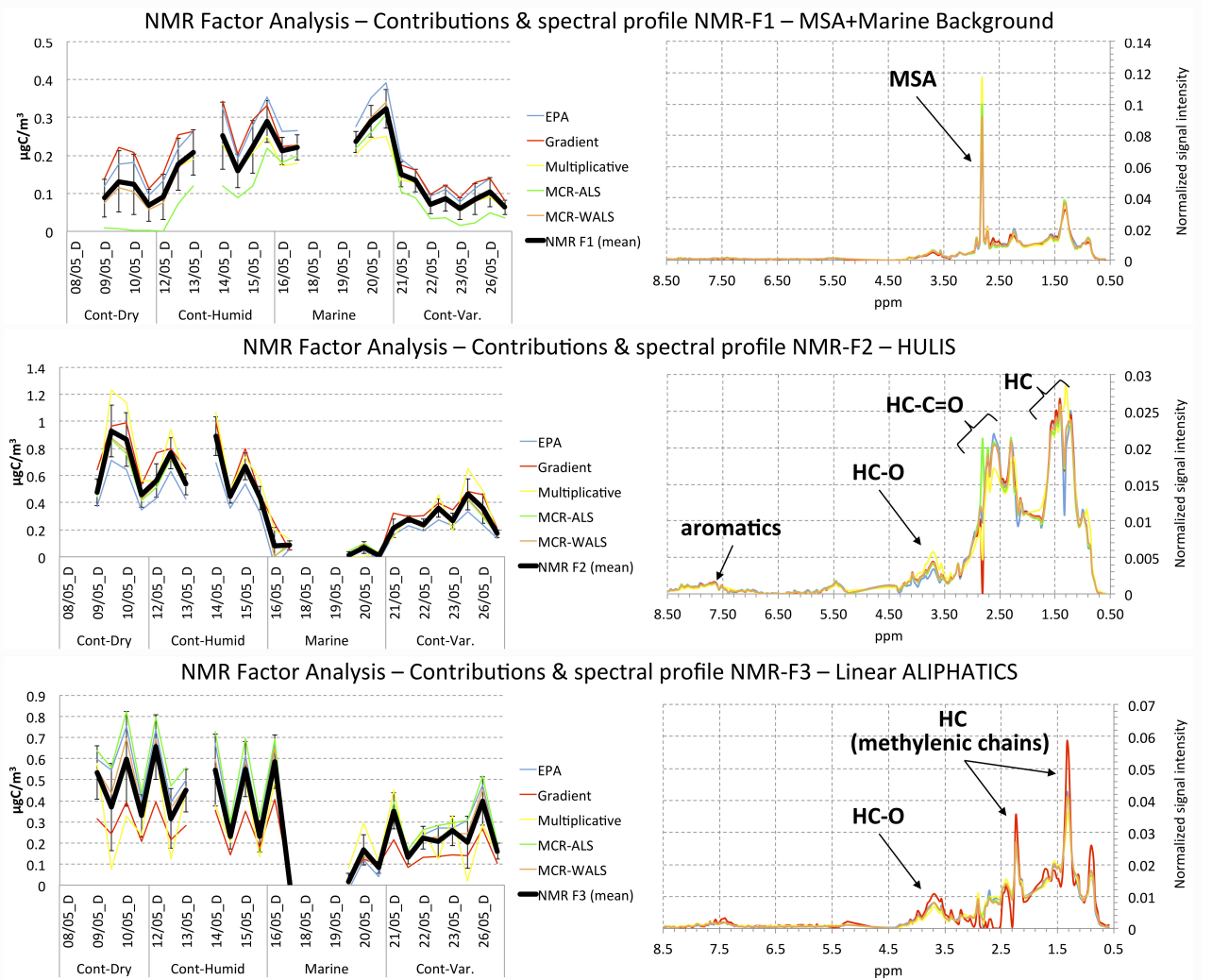

Fig. 1. Average $\mathrm{PM}_{1}$-filters' chemical composition and back-trajectory analysis for the four periods of the campaign. Organics are reported as total organic matter $(\mathrm{OM})$ calculated by the relationship $\mathrm{OM}=\mathrm{OC}_{\mathrm{PM}_{1}}$ filters $\cdot 1.6$.

Table 1. Periods of the campaign with average meteorological conditions.

\begin{tabular}{lccccc}
\hline & Days & Period ID & RH\% & Wind $\left(\mathrm{m} \mathrm{s}^{-1}\right)$ & Comments \\
\hline Period 1 & 9-12 May & Cont-Dry & 40.2 & 6.1 & Continental, windy, dry \\
Period 2 & 12-16 May & Cont-Humid & 71.4 & 4.0 & Continental, calm, humid \\
Period 3 & 17-21 May & Marine & 68.9 & 5.8 & Marine, windy, humid \\
Period 4 & 21-26 May & Cont-Var & 66.0 & 6.6 & Continental, variable \\
Whole IOP & & & 63.2 & 5.5 & \\
\hline
\end{tabular}

and the columns of matrix $g_{i k}$ represent the time-dependent contribution of each factor to the solution.

The number of factors is chosen based on residuum analysis for a range of solutions, together with correlation analysis of the factors with each other both in terms of mass-spectral and time-dependent similarities (Ulbrich et al., 2009). Each factor needs to be validated based on the knowledge of the mass spectrum characteristics and/or by correlation of the time dependence to so-called "tracers". Tracers are time series of compounds (a) measured by the AMS itself, e.g. nitrate $\left(\mathrm{NO}_{3}^{-}\right)$, sulfate $\left(\mathrm{SO}_{4}^{2-}\right)$, ammonium $\left(\mathrm{NH}_{4}^{+}\right)$, and chloride $\left(\mathrm{Cl}^{-}\right)$; (b) data of gas phase species like ozone $\left(\mathrm{O}_{3}\right)$, sulfur dioxide $\left(\mathrm{SO}_{2}\right)$, carbon monoxide $(\mathrm{CO})$, and nitrogen oxides $\left(\mathrm{NO}_{\mathrm{x}}\right)$; or $(\mathrm{c})$ particulate species like black carbon (BC) or elemental carbon (EC) acquired by collocated instru- ments. The major sources of ambient organic aerosol (OA) are strongly dependent on the measurement environment, but generally oxidized organic aerosol (OOA) and aliphatic (hydrocarbon-like, HOA) organic aerosol components are detected. In particular OOA is often divided into subclasses as discussed above.

\section{Results and discussion}

\subsection{Meteorological regimes and air mass origin}

Standard meteorological parameters were measured during the campaign. The first half of May 2008 was anomalously warm, with $T_{\max }$ reaching $25^{\circ} \mathrm{C}$ and staying above $20^{\circ} \mathrm{C}$ for 


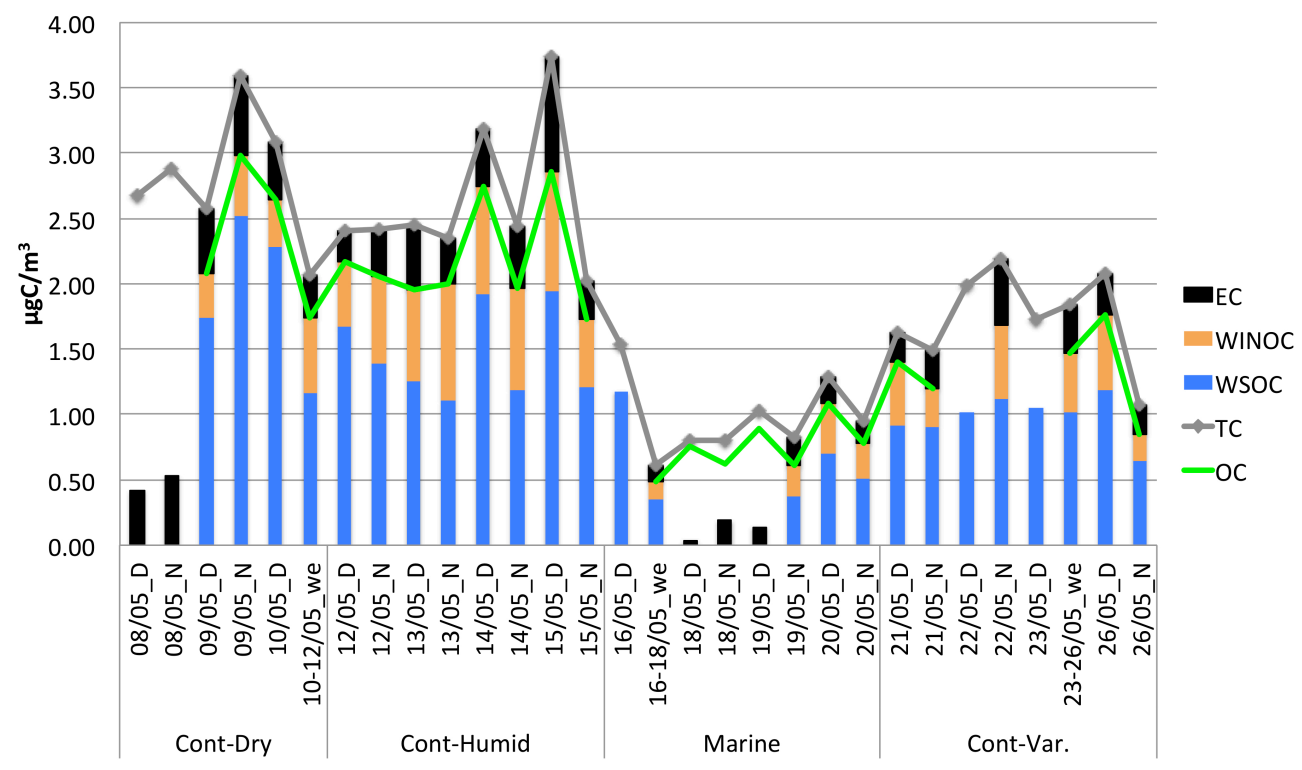

Fig. 2. Concentrations of total/organic/elemental (TC/OC/EC) carbon and of water-soluble organic carbon (WSOC) from evolved gas analysis (EGA) and thermo-oxidative analysis.

more than a week after the beginning of the experiment on 8 May. Winds were consistently from east and south-east, with only a brief period in the middle of the campaign (16 to 21 May) characterized by northerly winds, which also brought some rain to the site. During the campaign, the prevalent anticyclonic conditions over Central Europe favoured the accumulation of both primary and secondary aerosols in the planetary boundary layer, which can be regarded as a typical case of "regional pollution" (Hamburger et al., 2011).

Air-mass origins were examined using the NOAA HYSPLIT model (http://ready.arl.noaa.gov/HYSPLIT.php). Periodization of the field campaign was then carried out according to meteorological regimes and clusters of HYSPLIT back trajectories (Table 1, Fig. 1).

The first period (period 1, "continental, windy and dry", or Cont-Dry), lasting from 9 to 12 May, was characterized by generally dry and windy conditions and by easterly or south-easterly air masses. Period 2 (Cont-Humid, standing for "continental, calm and humid"), from 12 to 16 May, showed calm and humid characteristics and a continental air mass origin, similarly to Cont-Dry but with a northerly component (Fig. 1). The stable meteorological conditions were interrupted by an outbreak of Atlantic cold air masses between 17 and 21 May (period 3, "Marine") accompanied by strong winds, high humidity and precipitations. During period 4 ("continental, variable" or Cont-Var), lasting from 21 May to the end of the campaign, an easterly circulation was resumed, but with a larger day-to-day variability in temperature and humidity compared to the first half of the campaign.

\section{2 $\mathrm{PM}_{1}$ chemical composition from filter measurements}

Atmospheric concentrations of major aerosol chemical species experienced large variations during the campaign following the changes in air-mass origin. Almost the entire campaign was characterized by medium to high concentrations (Putaud et al., 2010) of sulfate, nitrate, ammonium, EC, potassium and oxalate (Table 2). Clearly, the persistent anticyclonic conditions over central Europe favoured the accumulation of both primary and secondary aerosols in the planetary boundary layer, which can be regarded as a typical case of "regional pollution" (Hamburger et al., 2011). During period 3 ("Marine"), the above aerosol species experienced a marked drop in concentration, while sodium, chloride and methanesulfonate (MSA) reached a maximum in terms of relative contributions, indicating that the aerosol particles reaching Cabauw from the ocean were likely of natural origin rather than originating from transatlantic transport of pollutants. Interestingly, Period 2 (Cont-Humid), even though characterized by easterly winds, showed high concentrations of marine aerosol together with the continental components, the former possibly coming from the recirculation of marine air masses travelling to Scandinavia and then turning south-west towards the Netherlands along the isobars of an Icelandic high-pressure system (Hamburger et al., 2011).

$\mathrm{PM}_{1}$ TC concentration spanned from 0.62 to $3.7 \mu \mathrm{g} \mathrm{m}^{-3}$ (Fig. 2). Organic carbon (OC) concentrations, ranging from 0.48 to $3.0 \mu \mathrm{g} \mathrm{m}^{-3}$, represented on average more than $80 \%$ of TC. The water-soluble organics fraction (WSOC) was generally high, accounting for $59 \%$ of TC and for $72 \%$ of OC on average. 
Table 2. Average concentrations ( $\mu \mathrm{gC} \mathrm{m}^{-3}$ for carbon measurements and $\mu \mathrm{g} \mathrm{m}^{-3}$ for the inorganic ions) of main chemical species in $\mathrm{PM}_{1}$ filters during the four periods of the campaign. Boldface numbers highlight the main differences in concentrations during the Marine period.

\begin{tabular}{lcccccccccccc}
\hline Periods & $\mathrm{TC}$ & $\mathrm{OC}$ & WSOC & $\mathrm{EC}$ & $\mathrm{NO}_{3}^{-}$ & $\mathrm{SO}_{4}^{2-}$ & $\mathrm{NH}_{4}^{+}$ & $\mathrm{MSA}$ & Oxalate & $\mathrm{K}^{+}$ & $\mathrm{Na}^{+}$ & $\mathrm{Cl}^{-}$ \\
\hline Cont-Dry & 2.75 & 2.26 & 1.88 & 0.43 & 0.82 & 1.71 & 0.55 & 0.06 & 0.17 & 0.03 & 0.23 & 0.02 \\
Cont-Humid & 2.54 & 2.08 & 1.44 & 0.47 & 1.78 & 1.73 & 1.03 & 0.18 & 0.14 & 0.03 & 0.19 & 0.05 \\
Marine & $\mathbf{1 . 0 6}$ & $\mathbf{0 . 8 7}$ & $\mathbf{0 . 5 7}$ & $\mathbf{0 . 1 9}$ & $\mathbf{0 . 8 4}$ & $\mathbf{0 . 8 7}$ & $\mathbf{0 . 3 9}$ & $\mathbf{0 . 2 4}$ & $\mathbf{0 . 0 3}$ & $\mathbf{0 . 0 1}$ & 0.16 & 0.03 \\
Cont-Var & 1.77 & 1.41 & 0.99 & 0.35 & 1.77 & 1.49 & 0.92 & 0.09 & 0.10 & 0.02 & 0.08 & 0.03 \\
Whole IOP & 2.05 & 1.67 & 1.22 & 0.37 & 1.38 & 1.48 & 0.76 & 0.14 & 0.11 & 0.02 & 0.16 & 0.03 \\
\hline
\end{tabular}

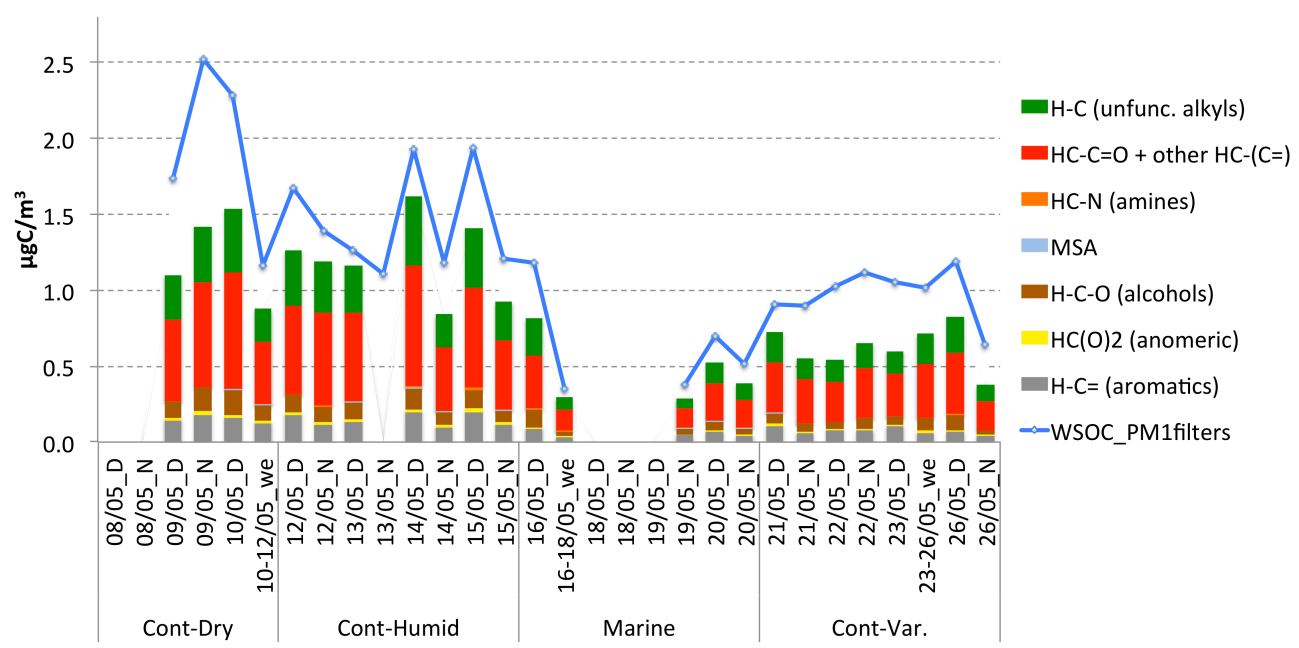

Fig. 3. Functional groups composition of $\mathrm{PM}_{1}$ filter samples by NMR analysis.

The average relative air mass composition in $\mathrm{PM}_{1}$ from filter measurements was calculated for the various periods of the campaign and for the whole observation period (Fig. 1). To this end, organic matter concentrations were derived from OC concentrations by assuming a conversion factor for $\mathrm{OM} / \mathrm{OC}$ of 1.6, in the range of the values recommended by previous studies (e.g. Bae et al., 2006; Russell, 2003). Results are in agreement with the data provided in parallel by the AMS (detailed in Mensah et al., 2012) with a dominant fraction (42\%) of organic matter, and $22 \%, 23 \%, 12 \%$ and $1 \%$ of nitrate, sulfate, ammonium and chloride, respectively. The distribution of the main aerosol components in $\mathrm{PM}_{1}$ was also influenced by air mass history, with greater contribution of organic compounds (54\%) during the first continental period (Cont-Dry) and larger shares of ammonium nitrate in the other periods (Fig. 1). In addition, it is worth mentioning that variations in chemical composition with air mass types observed here compare well with AMS observations carried out on board a research aircraft in the boundary layer over Europe during May 2008 (Crumeyrolle et al., 2013), showing a chemical composition with relative predominance of organics $(47 \%)$ for easterly air masses under anticyclonic condition (first half of May) and higher contributions of nitrate $(38 \%)$ in north-easterly air masses during cyclonic condition (second half of May).
The functional group concentrations measured by NMR spectroscopy in WSOC samples are reported in Fig. 3. Organic hydrogen concentrations were converted to organic carbon with the aim of comparing WSOC and OC concentrations. Stoichiometric $\mathrm{H} / \mathrm{C}$ ratios were specifically assigned to functional groups using the same rationale described in previous works (Decesari et al., 2007; Tagliavini et al., 2006). The main functional groups identified included alkyls (HC$\mathrm{C}<$ ), i.e. unsubstituted aliphatic groups; aliphatic groups substituted with carbonyls or carboxyls $(\mathrm{HC}-\mathrm{C}=\mathrm{O})$; aliphatic hydroxyls (HC-O); and finally aromatic functionalities (H-Ar). Minor functional groups include methyls or methylenes adjacent to N-H (amines) and S-O (MSA) substituents.

The average functional group distribution is dominated by aliphatic compounds which were either unsubstituted or substituted by carbonyls or carboxyls; hydroxyl and aromatic moieties were of minor importance. Such a composition indicates that fresh biomass burning compounds did not contribute significantly to WSOC; therefore, secondary sources are more likely (Decesari et al., 2007).

Although the sum of NMR functional group concentrations approached total WSOC in many samples, the uncharacterized fraction was significant (on average $29 \%$ ). Possible reasons for the "missing carbon" are (1) the presence of carbon atoms not attached to protons, thus invisible to NMR, 
such as oxalates and compounds containing substituted quaternary carbon atoms or fully substituted aryls (Moretti et al., 2008), and (2) evaporative losses during the evaporation of the extract prior to the preparation of the NMR tube.

\subsection{NMR-factors for WSOC}

This section discusses the results of factor analysis carried out with the five algorithms presented in Sect. 2.4.1, starting with the set of 25 NMR spectra at 200-point resolution. Solutions having two to eight factors were evaluated but, according to all algorithms, most of the variance was explained by a small number of factors. The largest drop in the $Q / Q_{\exp }$ ratios was recorded as being between two and three factors, while additional factors continued to reduce $Q / Q_{\exp }$ with a less marked change in slope (Fig. S1). Starting from the four-factor solution, two or more factors were found to be strongly correlated with each other (e.g. $R_{\mathrm{F} 3 \text { vs F4 }}=0.93$ as shown in Table S1 and Fig. S2), suggesting that the resolution of the chemical method or of the sampling was not adequate to differentiate additional independent factors. A full examination of the outcomes of NMR factor analysis is reported in the Supplement, while in this section we will focus on the three-factor solution, which shows a substantial agreement between all algorithms (Fig. 4a):

1. NMR factor $1\left(\mathrm{~F}_{\mathrm{NMR}}\right)$ "MSA-containing": the peak of methane-sulfonate (MSA) at $2.81 \mathrm{ppm}$ of chemical shift is most characteristic for this factor. Other spectral features include aliphatic chains with methylenes and terminal methyl peaks at respectively 1.3 and $0.8 \mathrm{ppm}$ of chemical shift. $\mathrm{F} 1_{\mathrm{NMR}}$ concentrations ranged from 0.1 to $0.5 \mu \mathrm{gC} \mathrm{m}^{-3}$, with a maximum during the marine period of the campaign; but they were also relatively high also during the Cont-Humid period. The occurrence of MSA as the major tracer compound and the characteristics of the concentration time trends assign NMR-F1 to marine WSOC transported directly from the Atlantic to the Netherlands during the "marine" period of the campaigns, or recirculated over the continent in the other periods. It can be considered a major contributor to the European continental background, becoming prominent in the days of northerly flow, as predicted by state-of-the-art chemical transport models (CTMs) (Athanasopoulou et al., 2013).

2. NMR factor 2 (F2 ${ }_{\mathrm{NMR}}$ ) "NMR-HULIS": the spectral characteristics of this factor are attributable to branched/cyclic and polysubstituted aliphatic compounds. Aliphatic chains with terminal methyls are almost absent and the hydroxyl groups also account for a very small fraction $(6 \%)$ of the detected WSOC. Conversely, the aliphatic groups substituted with $\mathrm{C}=\mathrm{C}$ and $\mathrm{C}=\mathrm{O}$ groups (between 1.8 and $3.2 \mathrm{ppm}$ ) represent on average $54 \%$ of the total functionalities on a carbon basis. Such spectral features were already re- ported for WSOC in environments impacted by continental anthropogenic emissions (Decesari et al., 2000, 2007, 2011; Finessi et al., 2012). Most interestingly, they overlap well with the NMR spectrum of Suwannee river fulvic acid (Fig. 4b). The "HULIS factor" accounted for $29 \%$ of TC and $48 \%$ of WSOC, and its concentration was highest during periods of continental (easterly) air masses. NMR-HULIS showed some correlation with sulfate $(R=0.62$, Fig. S3) suggesting that this WSOC fraction originated from secondary continental sources at the regional scale. Since the weather regimes during the campaign were characterized by prolonged high-pressure conditions over central and northern Europe, secondary processes of SOA formation occurred prevalently in a relatively dry, cloud-free atmosphere, suggesting that the secondary processes were likely not aqueous.

3. NMR factor 3 ( $\left.\mathrm{F} 3_{\mathrm{NMR}}\right)$ "linear aliphatics": this factor is characterized by compounds rich in linear aliphatic chains (peaks at 0.9 and $1.3 \mathrm{ppm}$ ) and less substituted compared to F2 ${ }_{\mathrm{NMR}}$ (NMR-HULIS). Linear aliphatic compound concentrations varied from 0.1 to $1 \mathrm{\mu gC} \mathrm{m}^{-3}$, with the highest values in periods of continental air masses. In contrast to the case of NMRHULIS, the linear aliphatic concentrations reached a maximum in daytime samples. This factor shows moderately positive correlations with tracers of primary sources, like EC, and also with aliphatic amines (Table 3 and Fig. S3), especially trimethylamine (TMA), which originates from agricultural practices. The contribution of linear aliphatics to WSOC seems to be linked to emissions in anthropogenic environments (heavily urbanized or agriculturally exploited) and may correspond to a "fresher" type of SOA than NMRHULIS. The positive correlation of a SOA component with primary emission tracers can originate from the effect of atmospheric transport combined with short formation timescales (Russell et al., 2009).

In conclusion, NMR factor analysis was able to apportion WSOC to three components, one marine and two showing continental sources. Moreover, the first two (MSAcontaining and NMR-HULIS) correlate with tracers of secondary aerosol, such as MSA and sulfate respectively, while the third one (linear aliphatics) showed a moderate correlation with anthropogenic primary and secondary tracers which point to processed POA or SOA with a less aged character than NMR-HULIS.

\subsection{Organic aerosol factors from AMS-PMF analysis}

The results of the AMS-PMF analysis are shown in Fig. 5. A four-factor solution was chosen for this data set, and the corresponding normalized mass spectra for each factor $(\mathrm{F} 1$ to F4) are shown on the left side of the figure. A whole 

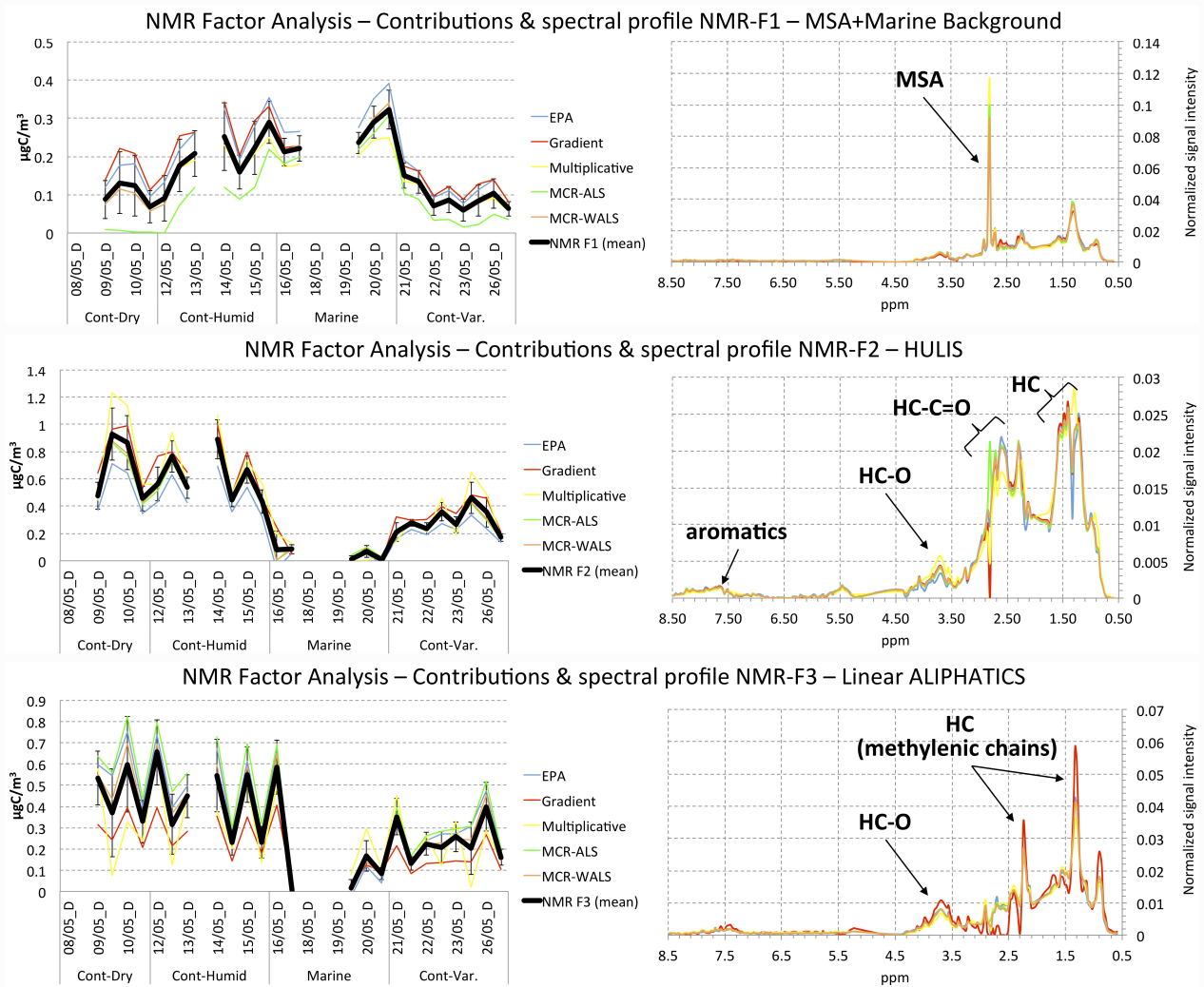

Fig. 4a. Profiles and contributions of 3-factors solution from NMR spectra factor analysis. Results from all five different algorithms and the average between them were reported: PMF from EPA free software (light blue line), projected gradient (red line), multiplicative (yellow line), MCR-ALS (green line) and MCR-WALS (orange line) methods and average value (with standard deviation bars) for contribution (thick black line in each graph).

Table 3. Correlations between NMR-factors and chemical data from $\mathrm{PM}_{1}$ filters.

\begin{tabular}{lccccccccc}
\hline$R$ (Pearson coefficient) & $\mathrm{TC} \mathrm{PM}_{1}$ & WSOC PM $_{1}$ & $\mathrm{EC} \mathrm{PM}_{1}$ & $\mathrm{OC} \mathrm{PM}_{1}$ & $\mathrm{TMA}$ & Amines & $\mathrm{NO}_{3}^{-} \mathrm{PM}_{1}$ & SO $_{4}^{2-} \mathrm{PM}_{1}$ & $\mathrm{HPLC}_{-} \mathrm{PA}$ \\
\hline NMR F1 (mean) & -0.16 & -0.19 & -0.15 & -0.19 & 0.09 & 0.18 & 0.00 & -0.32 & -0.38 \\
NMR F2 (mean) & 0.91 & 0.90 & 0.68 & 0.94 & 0.20 & 0.35 & 0.01 & 0.62 & 0.73 \\
NMR F3 (mean) & 0.73 & 0.79 & 0.55 & 0.84 & 0.46 & 0.43 & -0.22 & 0.56 & 0.69 \\
\hline
\end{tabular}

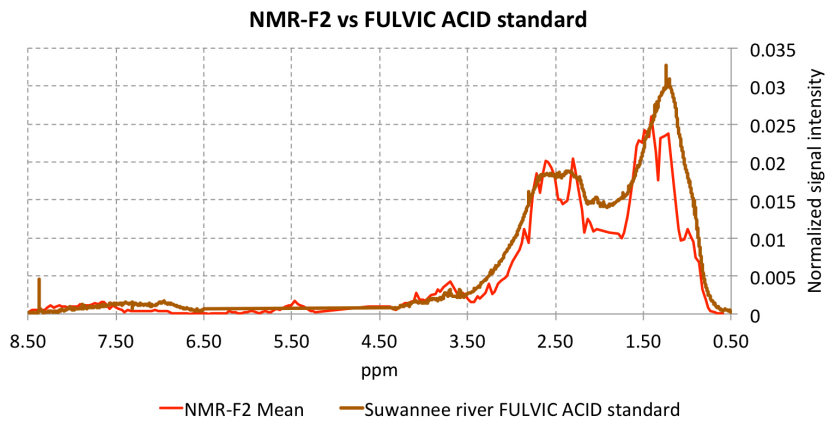

Fig. 4b. Spectral profile of NMR factor 2 (average profile) compared with the spectrum of the Suwannee River fulvic acid standard. range of mass spectra (obtained during laboratory, chamber, or field measurements) is presented on the AMS mass spectral database (Ulbrich et al., 2009) and can be used as reference spectra. Correlations of the factor mass spectra to the database mass spectra are presented in the Supplement (Fig. S4). The mass spectrum of the first factor (F1 AMs, bottom) is dominated by signals on $m / z 44$ and $m / z 18$, i.e. $\mathrm{CO}_{2}^{+}$and $\mathrm{H}_{2} \mathrm{O}^{+}$, respectively. Furthermore, significant signal intensity is assigned to $m / z 43$ (dominated by $\mathrm{C}_{2} \mathrm{H}_{3} \mathrm{O}^{+}$) and $m / z 29\left(\mathrm{COH}^{+}\right)$. Mass spectra of this type are associated with LV-OOA and the mass spectrum is very similar ( $R=0.99$ ) to the LV-OOA (former OOA1) spectrum measured at an urban background site in Zurich, Switzerland, by Lanz et al. (2007) (Fig. S4). The most dominant signal in the mass spectrum of factor $2(\mathrm{~F} 2 \mathrm{AMS}$ ) is on $m / z 43$, followed by 
the signals on $m / z 29, m / z 18, m / z 44$ and, $m / z 27$, as well as distinctive signal intensity on $m / z 55$ (mostly $\mathrm{C}_{3} \mathrm{H}_{3} \mathrm{O}^{+}$) and $m / z$ 91. SV-OOA is typically characterized by this mass spectrometric pattern (Lanz et al., 2007; Zhang et al., 2005, 2011). The mass spectrum of the third factor ( $\mathrm{F} 3 \mathrm{AMS}$ ) is dominated by peaks on $m / z 27\left(\mathrm{C}_{2} \mathrm{H}_{3}^{+}\right)$and $m / z 29\left(\mathrm{C}_{2} \mathrm{H}_{5}^{+}\right)$, $m / z 41\left(\mathrm{C}_{3} \mathrm{H}_{5}^{+}\right)$and $m / z 43\left(\mathrm{C}_{3} \mathrm{H}_{7}^{+}\right)$, and $m / z 55\left(\mathrm{C}_{4} \mathrm{H}_{7}^{+}\right)$ and $m / z 57\left(\mathrm{C}_{4} \mathrm{H}_{9}^{+}\right)$. These double peaks separated by 14 amu are characteristic for HOA and the mass spectrum shows high similarity $(R=0.92)$ to a HOA mass spectrum measured in Pittsburgh, USA in September 2002 by Zhang et al. (2005) (Fig. S4). The fourth mass spectrum representing $\mathrm{F} 4_{\mathrm{AMS}}$ is similar to $\mathrm{F} 1_{\mathrm{AMS}}$, being dominated by the peaks on $m / z 18$ and $m / z 44$, but the only other significant peaks are on $m / z 17, m / z 29$, and $m / z 40$, and almost no signal intensity is assigned to peaks above $m / z$ 44. This spectrum represents a highly oxygenated OA and is very similar to the mass spectrum of fulvic acid $(R=0.98)$ acquired in a laboratory experiment by Alfarra (2004) (Fig. S4). We refer to it as FA-OOA (Fulvic Acid-OOA) from here on. Since the measurement period was characterized by high photo-oxidation activity, the presence of a factor representing highly oxidized organic aerosol is not surprising.

Besides correlation to other mass spectra, the factors can also be characterized by correlation of their time series to the time series of possible tracers. On the right-hand side of Fig. 5, the time series of the four factors $\mathrm{F} 1_{\mathrm{AMS}}$ to $\mathrm{F} 4_{\mathrm{AMS}}$ (from bottom to top) are given together with corresponding tracers. LV-OOA is generally associated with the particulate sulfate fraction due to their common secondary sources and comparable low volatility. The time series of $\mathrm{F} 1_{\text {AMS }}$ (black line, bottom) corresponds well with the time series of particulate sulfate measured by the AMS (red line and axis). The time series of $\mathrm{F} 2$ AMS determined by PMF analysis corresponds well with semi-volatile nitrate measured by the AMS (blue line and axis). The time series of $\mathrm{F}_{\mathrm{AMS}}$ is very similar to the time trace of $\mathrm{BC}$ (brown line and axis), which is expected for HOA. BC data was obtained from a Multi Angle Absorption Photometer (MAAP 5012, Petzold and Schönlinner, 2004) operated by the Netherlands Applied Research Organisation (TNO). In order to ensure that the measured BC was not influenced by brown carbon (Andreae and Gelencsér, 2006), i.e. by light-absorbing organics like humic acid often found in biomass burning plumes (Gustafsson et al., 2009), the MS of F3 $3_{\text {AMS }}$ was correlated to the MS of humic acid obtained from laboratory measurements (Alfarra, 2004). An extremely low coefficient of determination $(R=0.30)$ was found, verifying that the HOA observed here is not influenced by brown carbon. This was expected, since significant biomass-burning activity is very unlikely for the Cabauw area in particular and western Europe in general. The time series of the NMR-HULIS is shown as green crosses together with the time series of the highly oxygenated $\mathrm{F} 4_{\mathrm{AMS}}$ in the top panel of the graph.
Table 4. OM / OC ratios determined for each PMF-factor by applying the general relationships found by Aiken et al. (2008) relating the fractional abundance of $\mathrm{m} / \mathrm{z} 44$ to the $\mathrm{O} / \mathrm{C}$ ratio and thereby to the $\mathrm{OM} / \mathrm{OC}$ ratio.

\begin{tabular}{lccc}
\hline AMS factor & $f_{44}(\%)$ & $\mathrm{O} / \mathrm{C}$ & $\mathrm{OM} / \mathrm{OC}$ \\
\hline 1 - LV-OOA & 15.8 & 0.68 & 2.04 \\
2 - SV-OOA & 5.3 & 0.28 & 1.54 \\
3 - HOA & 0.3 & 0.09 & 1.29 \\
4 - FA-OOA & 23.7 & 0.98 & 2.41 \\
\hline
\end{tabular}

\subsection{Comparison between NMR and AMS-factors for OA}

In this section, the AMS concentrations for particulate organic compounds are compared to those derived by NMR analyses. Since the different techniques employ different concentration units $\left(\mu \mathrm{g} \mathrm{m}^{-3}\right.$ of organic matter, mug $\mathrm{C} \mathrm{m}^{-3}$ of organic carbon, and mumol $\mathrm{H} \mathrm{m}^{-3}$ of organic hydrogen, respectively), stoichiometric ratios must be applied for quantitative comparison. In the following discussion, all AMS mass concentrations $\left(\mu \mathrm{g} \mathrm{m}^{-3}\right.$ ) are converted to $\mu \mathrm{gC} \mathrm{m}^{-3}$ by applying the general relationships found by Aiken et al. (2008) relating the fractional abundance of $\mathrm{m} / \mathrm{z} 44$ to the $\mathrm{O} / \mathrm{C}$ ratio and thereby to the $\mathrm{OM} / \mathrm{OC}$ ratio:

$\mathrm{O} / \mathrm{C}=0.038 \cdot f_{44}+0.0794$

$\mathrm{OM} / \mathrm{OC}=1.26 \cdot \mathrm{O} / \mathrm{C}+1.18$.

According to the equations above, OM/OC ratios of 2.04

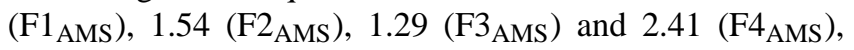
were obtained (Table 4).

As already mentioned, concentrations in carbon units $\left(\mu \mathrm{gC} \mathrm{m}^{-3}\right)$ for the NMR functional groups were derived from the measured concentrations in $\mu \mathrm{molH} \mathrm{m}{ }^{-3}$ by applying group-specific $\mathrm{H} / \mathrm{C}$ ratios.

Table 5a reports the correlation coefficients between main chemical species and $\mathrm{OC}$ factors obtained by the filter and AMS measurements. When comparing the $\mathrm{PM}_{1}$ filter concentrations for organic carbon and for inorganic ions (e.g. sulfate) with the time-integrated AMS concentrations (Fig. S5), a general underestimation of filters with respect to AMS is observed: ca. $16 \%$ less for sulfate and $33 \%$ for OC on average. Volatilization losses of semi-volatile organic compounds can be considered responsible for the reduced recovery of aerosol OC on filters compared to the AMS observations. Pearson correlation coefficients $(R)$ are only 0.39 for sulfate, 0.52 for nitrate, and somewhat better for OC (0.74) (Table 5a and Fig. S5). A comprehensive comparison of results from different instruments employed in the same campaign (AMS with SMPS and MARGA) was already carried out in Mensah et al. (2012); this comparison found, on the contrary, very good agreement between AMS and MARGA data and, if anything, implying an underestimation 

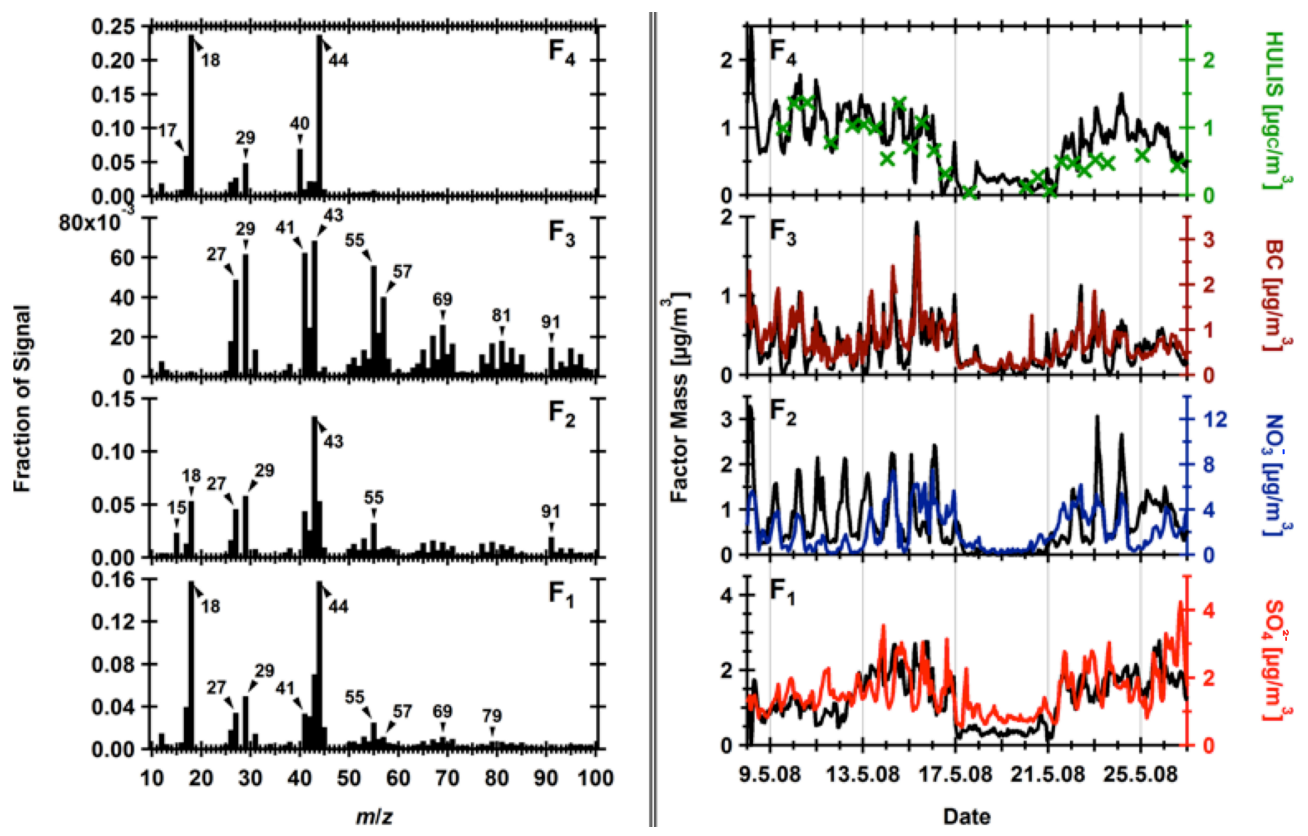

Fig. 5. Left: normalized mass spectra of the four factors, F1 to F4, (from bottom to top) determined by PMF analysis of the organic fraction of the 2008 measurements at CESAR tower. Right: time series of the PMF factors F1 to F4 (from bottom to top) determined for the organic mass fraction of the 2008 measurement period at CESAR tower. Factors (black lines, left axis) and the according tracers (coloured lines, right axes matching the respective trace in terms of colour) are given.

Table 5a. Correlations between AMS analyses and chemical data from filters and NMR analyses; boxes' colours follow the same scheme Boldface numbers highlight correlation between main aerosol components (OC, nitrate, sulfate) measured by $\mathrm{AMS}_{\text {and on }} \mathrm{PM}_{1}$ filters.

\begin{tabular}{|c|c|c|c|c|c|c|c|c|c|c|}
\hline$R$ (Pearson coefficient) & $\mathrm{TC} \mathrm{PM}_{1}$ & WSOC PM & $\mathrm{EC} \mathrm{PM}_{1}$ & $\mathrm{OC} \mathrm{PM}_{1}$ & $\mathrm{NO}_{3}^{-} \mathrm{PM}_{1}$ & $\mathrm{SO}_{4}^{2-} \mathrm{PM}_{1}$ & NMR F1 (mean) & NMR F2 (mean) & NMR F3 (mean) & HPLC_PA \\
\hline OOA AMS $\left(\mu \mathrm{g} \mathrm{m}^{-3}\right)$ & 0.70 & 0.58 & 0.58 & 0.70 & 0.22 & 0.62 & -0.35 & 0.76 & 0.43 & 0.62 \\
\hline OC AMS & 0.76 & 0.65 & 0.65 & 0.74 & 0.21 & 0.63 & -0.34 & 0.81 & 0.48 & 0.65 \\
\hline $\mathrm{NO}_{3}$ AMS & 0.16 & 0.03 & 0.37 & 0.15 & 0.52 & 0.17 & 0.01 & 0.00 & 0.03 & 0.17 \\
\hline $\mathrm{SO}_{4} \mathrm{AMS}$ & 0.25 & 0.16 & 0.30 & 0.27 & 0.46 & 0.39 & -0.39 & 0.21 & 0.18 & 0.28 \\
\hline AMS LV-OOA & 0.56 & 0.40 & 0.55 & 0.56 & 0.25 & 0.53 & -0.24 & 0.53 & 0.38 & 0.54 \\
\hline AMS SV-OOA & 0.57 & 0.51 & 0.42 & 0.58 & 0.29 & 0.53 & -0.34 & 0.69 & 0.30 & 0.52 \\
\hline AMS HOA & 0.66 & 0.52 & 0.83 & 0.67 & 0.30 & 0.42 & 0.12 & 0.44 & 0.48 & 0.61 \\
\hline AMS FA-OOA & 0.79 & 0.74 & 0.60 & 0.82 & -0.01 & 0.62 & -0.41 & 0.89 & 0.51 & 0.70 \\
\hline
\end{tabular}

of inorganics by the AMS. Although sampling artifacts can be blamed for the limited correlation of OC, the modest $R$ value found for sulfate, which is a stable, non-volatile compound, cannot be easily explained. Uncertainties in the fluxes of the dichotomous sampler, or the non-coincident sampling height $(60 \mathrm{~m}$ above the ground for AMS vs. ground-level for the dichotomous sampler), or sample loss due to small cracks we have found in some of the filters after sampling can be considered responsible for such discrepancies. The occurrence of a specific sampling artifact for the $\mathrm{PM}_{1}$ filters with respect to the AMS is witnessed by the fact that the average deviation between AMS and filter concentrations for sulfate is of the same magnitude as the deviation for the OC concentrations: the standard deviations of the difference are $0.59 \mu \mathrm{g} \mathrm{m}^{-3}$ for sulfate and $0.65 \mu \mathrm{gC} \mathrm{m}^{-3}$ for OC, which correspond to $34 \%$ and $27 \%$ of the average concentration levels for the two species measured by the AMS. In other words, the scatter of data between filter measurements and AMS concentrations is similar for sulfate and OC (Fig. S5). The more positive correlation found for the OC time trends determined by the two instruments (Table 5a) must be rooted in the more pronounced variations found for OC between periods of the campaign. In ANOVA terminology and defining four groups of samples corresponding to the periods in Table 1 , the sum of squares between groups weighs more in the variability of OC concentrations (78\% of the total sum of squares) compared to sulfate ( $47 \%$ of total sum of squares). In other words, since the sulfate concentration time trend is more stable, it is also more affected by possible sampling artifacts on filters with respect to AMS measurements, which in turn degrades the statistical correlation between the two series of observations. The corollary is that errors caused by instrumental reasons can be partly removed by taking averages over groups of samples and focusing on the variability 
Table 5b. Average concentrations for OC, sulfate, AMS and NMR factors in the four periods of the campaign and for nocturnal (N) and daytime (D) samples.

\begin{tabular}{|c|c|c|c|c|c|c|c|c|c|c|c|c|}
\hline & \multicolumn{4}{|c|}{ AMS factors $\mu \mathrm{g} \mathrm{m}^{-3}$} & \multicolumn{4}{|c|}{ AMS factors $\mu \mathrm{gC} \mathrm{m}^{-3}$} & \multicolumn{4}{|c|}{ AMS OC fractions } \\
\hline & LV-OOA & SV-OOA & HOA & FA-OOA & LV-OOA & SV-OOA & HOA & FA-OOA & LV-OOA & SV-OOA & HOA & FA-OOA \\
\hline C-WD & 1.43 & 1.16 & 0.52 & 1.55 & 0.70 & 0.76 & 0.40 & 0.64 & $28 \%$ & $30 \%$ & $16 \%$ & $26 \%$ \\
\hline $\mathrm{C}-\mathrm{CH}$ & 2.57 & 1.32 & 0.67 & 1.50 & 1.26 & 0.86 & 0.52 & 0.62 & $39 \%$ & $26 \%$ & $16 \%$ & $19 \%$ \\
\hline marine & 0.84 & 0.25 & 0.37 & 0.23 & 0.41 & 0.16 & 0.29 & 0.09 & $44 \%$ & $17 \%$ & $31 \%$ & $10 \%$ \\
\hline $\mathrm{C}-\mathrm{V}$ & 2.21 & 1.06 & 0.47 & 0.99 & 1.09 & 0.69 & 0.36 & 0.41 & $42 \%$ & $27 \%$ & $14 \%$ & $16 \%$ \\
\hline $\mathrm{N}$ & 1.94 & 1.20 & 0.48 & 1.15 & 0.95 & 0.78 & 0.37 & 0.48 & $37 \%$ & $30 \%$ & $14 \%$ & $18 \%$ \\
\hline \multirow[t]{3}{*}{$\mathrm{D}$} & 2.07 & 0.89 & 0.59 & 1.08 & 1.01 & 0.58 & 0.45 & 0.45 & $41 \%$ & $23 \%$ & $18 \%$ & $18 \%$ \\
\hline & \multicolumn{2}{|c|}{$\mathrm{SO}_{4}^{2-} \mu \mathrm{g} \mathrm{m}^{-3}$} & \multicolumn{2}{|c|}{$\mathrm{OC} \mu \mathrm{gC} \mathrm{m}^{-3}$} & \multicolumn{3}{|c|}{ NMR factors $\mu \mathrm{gC} \mathrm{m}^{-3}$} & \multicolumn{3}{|c|}{ NMR OC fractions } & & \\
\hline & $\mathrm{PM}_{1}$ & AMS & $\mathrm{PM}_{1}$ & AMS & $\mathrm{F} 1$ & $\mathrm{~F} 2$ & F3 & F1 & $\mathrm{F} 2$ & F3 & & \\
\hline C-WD & 1.73 & 1.45 & 2.36 & 2.49 & 0.10 & 0.68 & 0.46 & $4 \%$ & $29 \%$ & $19 \%$ & & \\
\hline $\mathrm{C}-\mathrm{CH}$ & 1.82 & 1.90 & 2.18 & 3.24 & 0.20 & 0.62 & 0.43 & $9 \%$ & $28 \%$ & $19 \%$ & & \\
\hline marine & 0.82 & 1.17 & 0.75 & 0.93 & 0.26 & 0.05 & 0.17 & $34 \%$ & $7 \%$ & $23 \%$ & & \\
\hline $\mathrm{C}-\mathrm{V}$ & 1.46 & 2.16 & 1.39 & 2.59 & 0.09 & 0.29 & 0.24 & $7 \%$ & $21 \%$ & $17 \%$ & & \\
\hline $\mathrm{N}$ & 1.45 & 1.93 & 1.65 & 2.61 & 0.17 & 0.42 & 0.22 & $10 \%$ & $26 \%$ & $13 \%$ & & \\
\hline $\mathrm{D}$ & 1.62 & 1.79 & 2.08 & 2.48 & 0.16 & 0.43 & 0.44 & $8 \%$ & $21 \%$ & $21 \%$ & & \\
\hline
\end{tabular}

between the four main periods of the campaign. To this aim, Table $5 \mathrm{~b}$ provides statistics for the AMS and $\mathrm{PM}_{1}$ filter concentrations of $\mathrm{OC}$ and sulfate and for the factors derived from factor analysis. Beside the classification between periods, the averages for nocturnal and diurnal samples are provided, too. Such average concentration values derived for subsets of samples will be used together with correlation coefficient between time trends (Table 5a) for the identification of possible overlaps between AMS and NMR organic factors. This approach does not allow assessing univocal correspondences between the AMS and the NMR factors, but rather indicates possible identifications. In general, we obtained a positive correlation between WSOC and the sum of AMS OOA types (AMS OOA types $=\mathrm{F} 1_{\mathrm{AMS}}+\mathrm{F} 2_{\mathrm{AMS}}+\mathrm{F} 4_{\mathrm{AMS}}$, expressed in carbon units in Table 5a) $(R=0.58)$. Looking at correlations between pairs of AMS vs NMR factors, the best match was found between $\mathrm{F} 4_{\mathrm{AMS}}$ (FA-OOA) and F2 ${ }_{\mathrm{NMR}}$ (NMRHULIS) with $R=0.89$ (Table 5a). The average concentrations of the two factors were also similar: $0.44 \mu \mathrm{gC} \mathrm{m}{ }^{-3}$ for $\mathrm{F} 4_{\mathrm{AMS}}$ and $0.40 \mu \mathrm{gC} \mathrm{m}^{-3}$ for NMR-HULIS. Concentrations of $\mathrm{F} 4_{\mathrm{AMS}}$ and $\mathrm{F} 2_{\mathrm{NMR}}$ were at a minimum in the period of marine air masses (period 3) and the contribution to total OC was highest in the first continental period (period 1) (Table $5 \mathrm{~b}$ ). The strong correlation between the two factors suggests that the highly oxidized OOA of F4 AMS is related to the polysubstituted aliphatic compounds identified by NMR analysis. We hypothesize that the same class of compounds, or "spectroscopic HULIS", was identified by both NMR and AMS in organic particles brought to Cabauw by continental air masses. Given the different sensitivity of the two techniques to specific functional groups, the AMS and NMR spectral fingerprints must be considered complementary. The NMR analysis is more sensitive to the aromatic rings and to the $\mathrm{C}-\mathrm{H}$ groups composing the backbone of HULIS, showing that it is mainly aliphatic and possessing no methylenic chains, while AMS fragmentation clearly provides information on the main oxygenated substituents, which appear to be carboxylic acid groups.

Finding equivalents between other AMS and NMR factors is more challenging. Factors showing nocturnal maxima in concentrations such as the AMS SV-OOA were not resolved by NMR factor analysis. The relatively high $\mathrm{R}$ value between $\mathrm{F} 2_{\mathrm{AMS}}$ and $\mathrm{F} 2_{\mathrm{NMR}}(0.69)$ reported in Table 5a seems not to indicate a real correspondence between these factors; this correlation, indeed, could be driven mainly by the fact that the F2 AMS undergoes a strong decrease of their concentrations during the Marine period also suffered by F2 $2_{\text {NMR }}$. However, the time series of those factors show that the F2 $2_{\mathrm{NMR}}$ had no systematic trends with the nocturnal maximum of $\mathrm{F} 2 \mathrm{AMS}$ (Figs. 4a and 5). Moreover, the deducible physico-chemical features of $\mathrm{F} 2 \mathrm{AMS}$ (characterized by less oxidized and semivolatile compounds, correlating with nitrate) did not match with those of $\mathrm{F} 2_{\mathrm{NMR}}$ (characterized by less volatile polysubstituted/branched aliphatic compounds similar to HULIS, and correlating better with sulfate). The reasons why NMR factor analysis missed a component with such a characteristic diurnal cycle such as the AMS SV-OOA is further discussed in Sect. 3.7.

By contrast, factors having a systematic maximum in daytime hours like $\mathrm{F} 3_{\mathrm{NMR}}$ had no equivalent in PMF-AMS. On some days of the campaign, the concentrations of $\mathrm{F} 3_{\mathrm{NMR}}$ (linear aliphatics) seem to closely follow those of $\mathrm{F} 1_{\mathrm{AMS}}$, like at the end of the period Cont-Humid (15 and 16 May) which closely precedes the marine air outbreak, when the concentrations of the HULIS ( $\mathrm{F} 2_{\mathrm{NMR}}$ and $\mathrm{F} 4_{\mathrm{AMS}}$ ) dropped steadily while those of NMR linear aliphatics and of $\mathrm{F} 1_{\text {AMS }}$ remained high. However, the overall time trends of $\mathrm{F} 3_{\mathrm{NMR}}$ and $\mathrm{F} 1_{\mathrm{AMS}}$ show only a limited overlap $(R=0.38)$ and, given that the concentrations of $\mathrm{F} 1_{\mathrm{AMS}}$ are much larger than 
those of $\mathrm{F} 3_{\mathrm{NMR}}$, the latter may be considered, rather, a fraction of the class of compounds identified as $\mathrm{F} 1_{\mathrm{AMS}}$.

NMR factor analysis did not identify a factor matching with $\mathrm{F}_{3}$ AMS (HOA) because poorly oxygenated hydrocarbons do not contribute significantly to WSOC.

Finally, factor analysis applied to the NMR data set accounts for a distinct factor associated with organic aerosols from marine sources, the MSA-containing $\left(\mathrm{F} 1_{\mathrm{NMR}}\right)$, enriched in period 3 of the campaign, with no equivalent resolved by the AMS-PMF analysis. It should be noticed, however, that the AMS was actually able to detect a specific mass fragment of $\mathrm{MSA}, \mathrm{CH}_{3} \mathrm{SO}_{2}^{+}$. Taking the concentration of $\mathrm{CH}_{3} \mathrm{SO}_{2}^{+}$and the observed ratio of $\mathrm{CH}_{3} \mathrm{SO}_{2}^{+} / \mathrm{CH}_{4} \mathrm{SO}_{3}^{+}$of 4.5 , the concentration of MSA was calculated by applying the fragmentation pattern provided by Langley et al. (2010). The MSA time trend was well correlated with the results of the offline analysis (both IC and NMR with $R=0.84$ and 0.74 respectively) (Fig. 6) but the AMS-derived concentration of MSA was considerably lower $(15 \%$ and $10 \%$ of ICMSA and $\mathrm{F} 1_{\mathrm{NMR}}$ respectively). In other words, the MSA mass tracer from the AMS clearly showed the increase of marine SOA during the second continental period of the campaign and during the days of northerly flow towards Cabauw. At the same time, MSA signals were only a minor fragment in the AMS spectra, and its variability was not captured by PMF to identify a specific factor, equivalent to the $F 1_{\mathrm{NMR}}$. This is another example of the different NMR and AMS sensitivities to specific functional groups, which in turn affects the outcomes of factor analysis.

Overall, the picture emerging from the NMR factor analysis is conceptually more similar to that provided by CTMs describing the organic aerosol concentration at the Cabauw site as a consequence of the build-up of SOA and POA from continental sources over a non-negligible continental background (Athanasopoulou et al., 2013). At the same time, the AMS, due to its much higher time resolution and to its greater sensitivity to $\mathrm{O} / \mathrm{C}$ ratios, was able to provide a better split between more or less oxidized/processed OOAs.

\subsection{Comparison of HULIS from chromatographic and spectroscopic techniques}

HULIS are classified as polycarboxylic acids using the HPLC-TOC method presented in Sect. 2.2.6. Such a technique is a derivation of the very first method used for HULIS analysis (Havers et al., 1998), and it is based on retention characteristics of fractions of WSOC with respect to a standard of aquatic fulvic acids. Therefore, polyacids or "chromatographic HULIS" must be considered HULIS sensu stricto. The resulting concentrations for polyacids were compared with NMR and AMS concentrations for HULIS. Polyacids correlated weakly with both $\mathrm{F} 2{ }_{\mathrm{NMR}}(R=0.73)$ and F4 AMS $(R=0.70)$ (Fig. 7). Nevertheless, chromatographic HULIS represented only $30 \%$ of $\mathrm{F} 2{ }_{\mathrm{NMR}}$ and $27 \%$ of F 4 AMS. These results provide confirmation that the organic materials exhibiting spectral properties similar to those of fulvic acids are related to HULIS sensu stricto determined from chemical methods. At the same time, they also include chemical species which are not real polycarboxylic acids. Previous studies on atmospheric HULIS (Graber and Rudich, 2006) had already highlighted differences between atmospheric HULIS and terrestrial and aquatic humic substances, including lower aromaticity (19\% (Tagliavini et al., 2006) against 31-58 \% (IHSS, www.ihss.gatech.edu9)), higher H/C molar ratios (1.42-1.58 (Kiss et al., 2002; Krivácsy et al., 2001) versus 0.91-0.99 (IHSS, www.ihss.gatech.edu)), weaker acidic nature and especially smaller molecular size for atmospheric HULIS (500-1000 Da (Havers et al., 1998; Krivácsy et al., 2001; Kiss et al., 2003) versus 1000-10 000 Da (Aiken, 1984; Marley et al., 1992)). In agreement with the studies mentioned above, we observed that very oxidized carboxylic acids (which are lighter than fulvic acids) contributed to $\mathrm{F} 4{ }_{\mathrm{AMS}}$ and to $\mathrm{F} 2_{\mathrm{NMR}}$ while showing a smaller retention coefficient on SPE columns with respect to chromatographic HULIS. Since neither AMS nor NMR provide direct information on molecular size, we hypothesize that spectroscopic HULIS are actually a class of carboxylic acids spanning over a wide range of molecular weights and whose larger homologous species correspond to the polyacids or HULIS sensu stricto.

\subsection{Link between AMS factors and water-insoluble organic carbon}

AMS hydrocarbon-like organic aerosol (HOA) is characterized by very low oxygen content $(\mathrm{O} / \mathrm{C} \sim 0.1)$ and can be considered essentially water-insoluble. It accounts for mainly primary compounds showing concentrations well correlated with those of EC $(R=0.83)$ and $\mathrm{BC}(R=0.94)$. Nevertheless, HOA (F3 $3_{\mathrm{AMS}}$ ) alone could not explain the whole waterinsoluble organic carbon fraction, as it represents on average only $77 \%$ of WINOC measured on PM $_{1}$ filters. The remaining portion of WINOC could be attributed to fractions of the SV-OOA, which account for OA compounds characterized by intermediate $\mathrm{O} / \mathrm{C}$ ratios compared to LV-OOA and HOA, respectively. Therefore, SV-OOA might show only a partial solubility in water, which could explain why NMR analysis did not find any factors within WSOC showing the nocturnal enrichment characteristic of semi-volatile compounds such as $\mathrm{F} 2 \mathrm{AMS}$ (SV-OOA) and ammonium nitrate. Another explanation for a missing semi-volatile fraction from NMR analysis could be evaporation losses during sample treatment prior to NMR analysis.

To summarize the comparison between the NMR and AMS factors including water-insoluble compounds, we provide a tentative mass budget (Fig. 8) for aerosol OC as a campaign average, with our best hypothesis of overlap between carbon classes derived from filter analysis and those determined by the online measurement (AMS). The fact that OC measured on $\mathrm{PM}_{1}$ filters was lower than the carbon 


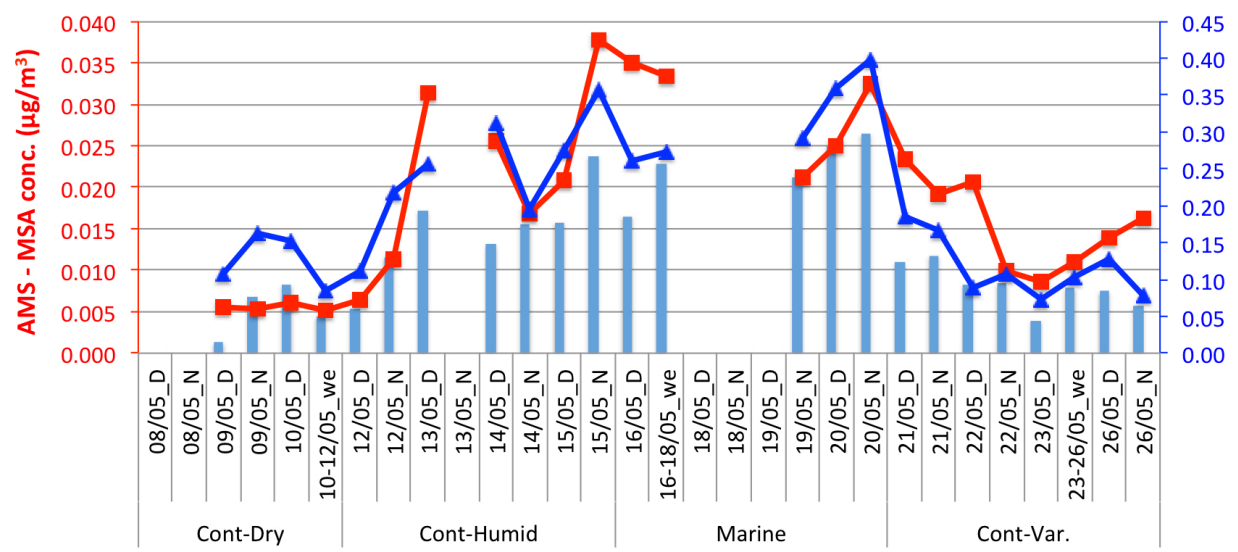

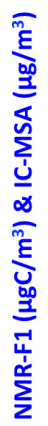

Fig. 6. Comparison between IC measurements for MSA, average NMR MSA-containing factor (referring to right blue axis) and AMS estimation of MSA concentrations from tracer ion $\mathrm{CH}_{3} \mathrm{SO}_{2}^{+}$(left red axis).

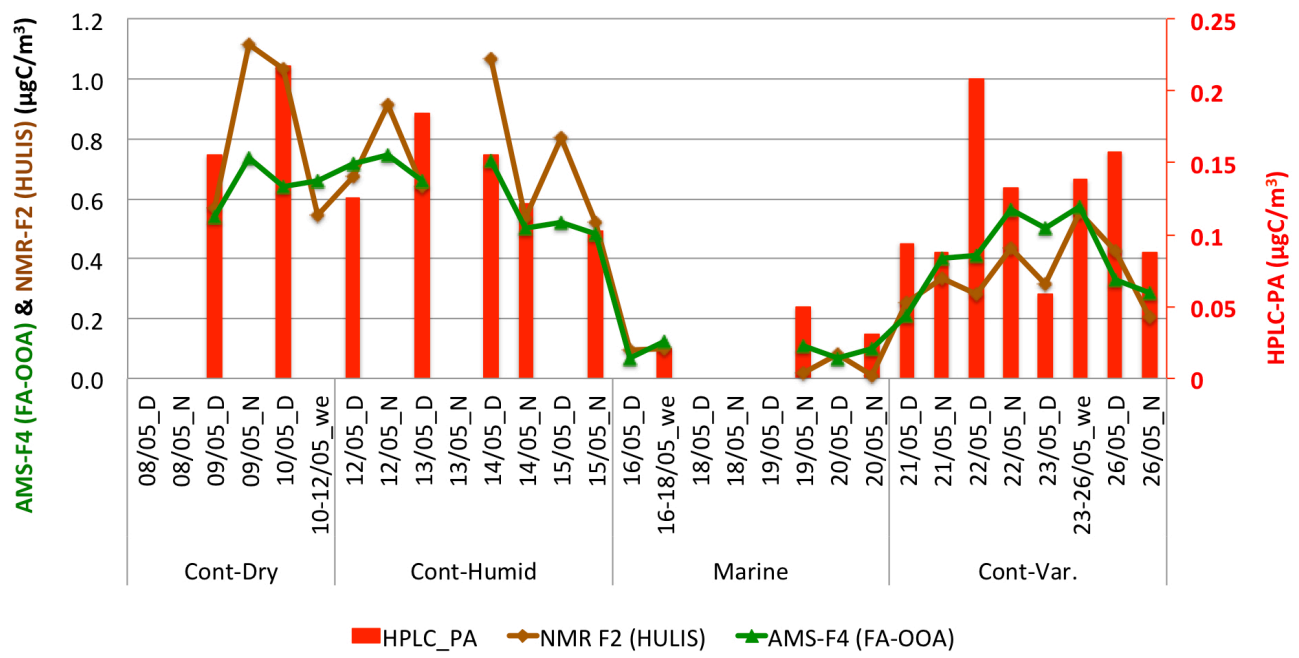

Fig. 7. Comparison between HPLC PA fraction, AMS-F4 and NMR-F2: the figure reports time series of AMS and NMR factors (left black axis) and of HPLC PA fraction (right red axis).

associated with organic matter measured by the AMS together with the low time resolution of filter collection allow only a tentative assignment to the NMR and AMS carbon classes. However, we can observe that (a) there is an excess of water-insoluble carbon on filters compared to the HOA (F3 $3_{\mathrm{AMS}}$ ) from the AMS, suggesting that the least-oxygenated fractions of OOAs contributed to some extent to WINOC; (b) there were some semi-volatile compounds within WSOC which were lost during sample preparation for NMR analysis and which most likely encompass most of to F2 AMS (SV-OOA); (c) the carbon budget (Fig. 8) at the light of the above considerations indicates that $\mathrm{F} 1_{\mathrm{AMS}}$ (LV-OOA) must take into account some of the WSOC not already included in $\mathrm{F} 2_{\mathrm{NMR}}$, and therefore compounds traced by $\mathrm{F} 1_{\mathrm{NMR}}$ and $\mathrm{F} 3{ }_{\text {NMR }}$ must contribute to $\mathrm{F} 1_{\mathrm{AMS}}$ (LV-OOA).

Clearly, both techniques highlighted the occurrence of water-soluble HULIS, whereas the other factors could not be reduced to a simple classification scheme common to AMS and NMR in this study.

\section{Conclusions}

Submicron organic aerosol observations made with offline (NMR, IC, HPLC) and online (AMS) techniques were performed at Cabauw, the Netherlands, in May 2008. This period was characterized by prolonged stable anticyclonic conditions, which favoured the accumulation of pollutants over western/central Europe, interrupted by an outbreak of Atlantic air masses between 17 and 20 May.

Factor analysis applied to NMR spectra collections provided an apportionment of WSOC into chemical classes defined by distinct functional group compositions. AMS PMFfactor analysis was performed, and results from both data sets were compared. In spite of issues related to the recovery of 


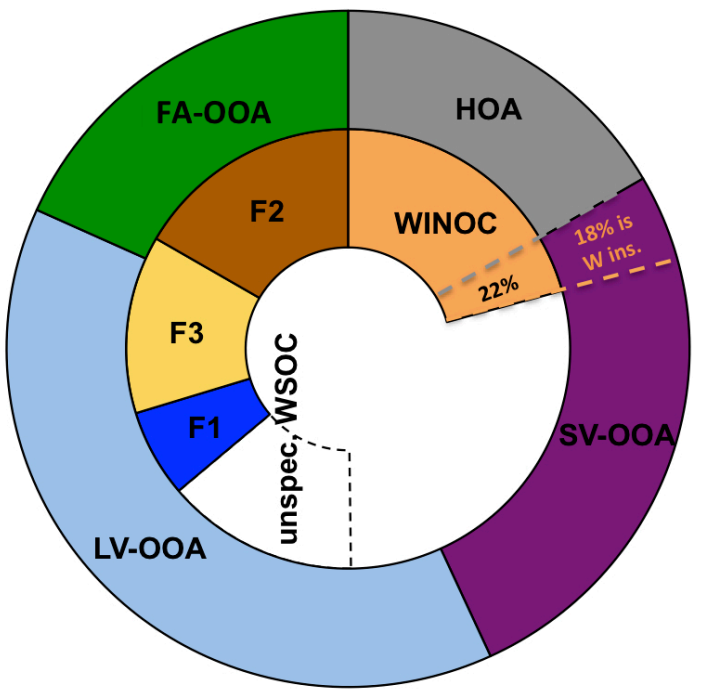

Fig. 8. Organic carbon (OC) amount and comparison between the three different techniques used. Inner circle reports data from NMR and filters analyses; the outer one those from AMS.

offline analysis in respect to sampling and sample preparation, the NMR/AMS comparison provided new insights into the chemical nature of AMS factors for OOA. In particular, a good correspondence between branched/cyclic polysubstituted compounds without methylenic chains and the most oxidized AMS aerosol type (F4 AMS $_{\text {S }}$ ) was observed. The two spectral fingerprints point to the same class of compounds which was classified with atmospheric HULIS.

Polycarboxylic acids isolated from WSOC in the filter aqueous extracts by a HPLC procedure (HULIS sensu stricto) showed concentrations positively correlated with those of the spectroscopic HULIS from NMR and AMS, although chromatographic HULIS concentrations were generally smaller, suggesting that they are only a subclass $(\sim 30 \%)$ of the highly oxygenated organic compounds showing the spectroscopic features of HULIS.

Fewer similarities were observed between the other classes of organic aerosol components identified separately by AMS and NMR factor analysis, with no simple scheme of assignment. Carbon budget calculations suggest that the NMR class of linear aliphatic compounds, interpreted as fresh SOA or processed POA, can contribute to AMS LV-OOA ( $\mathrm{F}_{\mathrm{AMS}}$ ) which is less oxidized than HULIS, and may reflect an earlier stage of atmospheric aging. The lack of suitable NMR factors matching the time trends of AMS SV-OOA ( $\mathrm{F}_{2} \mathrm{AMS}$ ) could be due to limited water solubility or sample loss by volatilization. Finally, the NMR factor analysis highlighted a component associated with northerly (marine) air masses and air masses rich in methanesulfonate. This class of compounds was found to dominate the organic composition in Cabauw in background conditions. No specific AMS factor for marine organics was discriminated by PMF, though an
AMS mass tracer for MSA $\left(\mathrm{CH}_{3} \mathrm{SO}_{2}\right)$ was found in small concentrations, showing a time trend in good agreement with the results of offline analyses.

The "continental" nature of HULIS emerging from the Cabauw experiment was confirmed by additional NMR measurements at other EUCAARI stations during May 2008 (taken in preparation) showing that the NMR-HULIS factor $\left(\mathrm{F} 2_{\mathrm{NMR}}\right)$ characterized the WSOC composition in the polluted boundary layer air in easterly air masses flowing from central Europe to the British Isles (from the K-Puszta station in Hungary, to Melpitz in Germany, to Mace Head in Ireland). Therefore, despite the still-scarce knowledge of HULIS sources and atmospheric fate, the oxidized organic compounds detected by NMR as HULIS were common constituents of submicron aerosols at the regional scale over Europe. Contrary to $\mathrm{F} 2_{\mathrm{NMR}}$ (HULIS), the aliphatic-rich WSOC (linear aliphatics, $\mathrm{F} 3_{\mathrm{NMR}}$ ) of Cabauw was not found in the central European stations. This could be related to different sources of oxidized organic aerosols at that time in the North Sea area.

In conclusion, this study shows that the picture of the chemical composition of the organic fraction of the aerosol is more complex than AMS or NMR can individually explain. Conversely, identification of "factors" in multiple spectroscopic methods, indicate that the chemical structures underlying factors correspond to "real" chemical classes rather than being mere collections of spectral signals extracted by statistical algorithms. Therefore, the use of complementary spectroscopic techniques during field experiments is a powerful tool to test and constrain the conceptual schemes of particulate organic compound categorization and evolution in the atmosphere which have been proposed in the recent literature.

\section{Supplementary material related to this article is available online at http://www.atmos-chem-phys.net/14/ 25/2014/acp-14-25-2014-supplement.pdf.}

Acknowledgements. This work was funded by the European integrated project on aerosol cloud climate and air quality interactions (No. 036833-2, EUCAARI). We gratefully thank the technical personnel at KNMI for its precious assistance at the Cabauw site during the EUCAARI - IOP. We also thank Dr. Matteo Stocchero (S-IN Soluzioni Informatiche) for his valuable suggestions regarding the statistical analysis of the NMR data set.

Edited by: L. M. Russell

\section{References}

Aiken, G. R.: Evaluation of ultrafiltration for determining molecular weight of fulvic acid, Environ. Sci. Technol., 18, 978-981, 1984.

Aiken, A.C., DeCarlo, P. F., Kroll, J. H., Worsnop, D. R., Huffman, J. A., Docherty, K., Ulbrich, I. M., Mohr, C., Kimmel, J. 
R., Sueper D., Zhang Q., Sun, Y., Trimborn, A., Northway, M., Ziemann, P. J., Canagaratna, M. R., Onasch, T. B., Alfarra, M. R., Prévôt, A. S. H., Dommen, J., Duplissy, J., Metzger, A., Baltensperger, U., and Jimenez, J. L.: O/C and OM/OC ratios of primary, secondary, and ambient organic aerosols with high resolution time-of-flight aerosol mass spectrometry, Environ. Sci. Technol., 42, 4478-4485, 2008.

Aiken, A. C., Salcedo, D., Cubison M. J., Huffman, J. A., DeCarlo, P. F., Ulbrich, I. M., Docherty, K. S., Sueper, D., Kimmel, J. R., Worsnop, D. R., Trimborn, A., Northway M., Stone, E. A., Schauer, J. J., Volkamer, R. M., Fortner, E., de Foy, B., Wang, J., Laskin, A., Shutthanandan, V., Zheng, J., Zhang, R., Gaffney, J., Marley, N. A., Paredes-Miranda, G., Arnott, W. P., Molina, L. T., Sosa, G., and Jimenez, J. L.: Mexico City aerosol analysis during MILAGRO using high resolution aerosol mass spectrometry at the urban supersite (T0) - Part 1: Fine particle composition and organic source apportionment, Atmos. Chem. Phys., 9, 6633-6653, doi:10.5194/acp-9-6633-2009, 2009.

Alfarra, M. R., Coe, H., Allan, J. D., Bower, K. N., Boudries, H., Canagaratna, M. R., Jimenez, J. L., Jayne, J. T., Garforth, A. A., Li, S. M., and Worsnop, D. R.: Characterization of urban and rural organic particulate in the lower Fraser valley using two Aerodyne aerosol mass spectrometers, Atmos. Environ., 38, 57455758, 2004.

Alfarra, M. R., Paulsen, D., Gysel, M., Garforth, A. A., Dommen, J., Prévôt, A. S. H., Worsnop, D. R., Baltensperger, U., and Coe, H.: A mass spectrometric study of secondary organic aerosols formed from the photooxidation of anthropogenic and biogenic precursors in a reaction chamber, Atmos. Chem. Phys., 6, 5279-5293, doi:10.5194/acp-6-5279-2006, 2006.

Andreae, M. O. and Gelencsér, A.: Black carbon or brown carbon? The nature of light-absorbing carbonaceous aerosols, Atmos. Chem. Phys., 6, 3131-3148, doi:10.5194/acp-6-3131-2006, 2006.

Aouizerats, B., Thouron, O., Tulet, P., Mallet, M., Gomes, L., and Henzing, J. S.: Development of an online radiative module for the computation of aerosol optical properties in 3-D atmospheric models: validation during the EUCAARI campaign, Geosci. Model Dev., 3, 553-564, doi:10.5194/gmd-3-553-2010, 2010.

Athanasopoulou, E., Vogel, H., Vogel, B., Tsimpidi, A. P., Pandis, S. N., Knote, C., and Fountoukis, C.: Modeling the meteorological and chemical effects of secondary organic aerosols during an EUCAARI campaign, Atmos. Chem. Phys., 13, 625-645, doi:10.5194/acp-13-625-2013, 2013.

Baduel, C., Voisin, D. and Jaffrezo, J.-L.: Seasonal variations of concentrations and optical properties of water soluble HULIS collected in urban environments, Atmos. Chem. Phys., 10, 40854095, doi:10.5194/acp-10-4085-2010, 2010.

Bae, M.-S., Demerjian, K. L., and Schwab, J. J.: Seasonal estimation of organic mass to organic carbon in $\mathrm{PM}_{2.5}$ at rural and urban locations in New York state, Atmos. Environ., 40, 74677479, doi:10.1016/j.atmosenv.2006.07.008, 2006.

Birch, M. E. and Cary R. A.: Elemental carbon-based method for occupational monitoring of particulate diesel exhaust: methodology and exposure issues, Analyst, September 1996, 121, 11831190, 1996.

Canagaratna, M. R., Jayne, J. T., Jimenez, J. L., Allan, J. D., Alfarra, M. R., Zhang, Q., Onasch, T. B., Drewnick, F., Coe, H.,
Middlebrook, A., Delia, A., Williams, L. R., Trimborn, A. M., Northway, M. J., DeCarlo, P. F., Kolb, C. E., Davidovits, P., and Worsnop, D. R.: Chemical and microphysical characterization of ambient aerosols with the aerodyne aerosol mass spectrometer, Mass Spectrom. Rev., 26, 185-222, 2007.

Cavalli, F., Facchini, M. C., Decesari, S., Mircea, M., Emblico, L., Fuzzi, S., Ceburnis, D., Yoon, Y. J., O’Dowd, C. D., Putaud, J.-P., and Dell'Acqua, A.: Advances in characterization of size-resolved organic matter in marine aerosol over the North Atlantic, J. Geophys. Res., 109, D24215, doi:10.1029/2004JD005137, 2004.

Cavalli, F., Viana, M., Yttri, K. E., Genberg, J. and Putaud, J.-P.: Toward a standardised thermal-optical protocol for measuring atmospheric organic and elemental carbon: the EUSAAR protocol, Atmos. Meas. Tech., 3, 79-89, doi:10.5194/amt-3-79-2010, 2010.

Crumeyrolle, S., Schwarzenboeck, A., Roger, J. C., Sellegri, K., Burkhart, J. F., Stohl, A., Gomes, L., Quennehen, B., Roberts, G., Weigel, R., Villani, P., Pichon, J. M., Bourrianne, T., and Laj, P.: Overview of aerosol properties associated with air masses sampled by the ATR-42 during the EUCAARI campaign (2008), Atmos. Chem. Phys., 13, 4877-4893, doi:10.5194/acp-13-48772013, 2013.

DeCarlo, P. F., Kimmel, J. R., Trimborn, A., Northway, M. J., Jayne, J. T., Aiken, A. C., Gonin, M., Fuhrer, K., Horvath, T., Docherty, K. S., Worsnop, D. R., and Jimenez, J. L.: Field-deployable, high-resolution, time-of-flight aerosol mass spectrometer, Anal. Chem., 78, 8281-8289, 2006.

Decesari, S., Facchini, M. C., Fuzzi, S., and Tagliavini, E.: Characterization of water-soluble organic compounds in atmospheric aerosol: A new approach, J. Geophys. Res., 105, 1481-1489, 2000.

Decesari, S., Facchini, M. C., Matta, E., Lettini, F., Mircea, M., Fuzzi, S., Tagliavini, E., and Putaud, J. P.: Chemical features and seasonal variation of fine aerosol water-soluble organic compounds in the Po Valley, Italy, Atmos. Environ., 35, 3691-3699, 2001.

Decesari, S., Mircea, M., Cavalli, F., Fuzzi, S., Moretti, F., Tagliavini, E., and Facchini, M. C.: Source attribution of water-soluble organic aerosol by nuclear magnetic resonance spectroscopy, Environ. Sci. Technol., 41, 2479-2484, 2007.

Decesari, S., Finessi, E., Rinaldi, M., Paglione, M., Fuzzi, S., Stephanou, E. G., Tziaras, T., Spyros, A., Ceburnis, D., O’Dowd, C., Dall'Osto, M., Harrison, R. M., Allan, J., Coe, H., Facchini, M. C.: Primary and secondary marine organic aerosols over the North Atlantic Ocean during the MAP experiment, J. Geophys. Res., 116, D22210, doi:10.1029/2011JD016204, 2011.

Derksen, J. W. B., Roelofs, G.-J. H., Otjesb, R., de Leeuw, G., Röckmann, T.: Impact of ammonium nitrate chemistry on the AOT in Cabauw, the Netherlands, Atmos. Environ., 45, 5640-5646, doi:10.1016/j.atmosenv.2011.02.052, 2011.

Dinar, E., Taraniuk, I., Graber, E. R., Anttila, T., Mentel, Th. F., and Rudich, Y.: Hygroscopic growth of atmospheric and model humic-like substances, J. Geophys. Res., 112, D05211, doi:10.1029/2006JD007442, 2007.

Drewnick, F., Schwab, J. J., Jayne, J. T., Canagaratna, M., Worsnop, D. R., Demerjian, K. L.: Measurement of Ambient Aerosol Composition During the PMTACS-NY 2001 Using an Aerosol Mass 
Spectrometer. Part I: Mass Concentrations, Aerosol Sci. Technol., 38, 92-103, doi:10.1080/02786820390229507, 2004.

El Haddad, I., D’Anna, B., Temime-Roussel, B., Nicolas, M., Boreave, A., Favez, O., Voisin, D., Sciare, J., George, C., Jaffrezo, J.-L., Wortham, H., and Marchand, N.: Towards a better understanding of the origins, chemical composition and aging of oxygenated organic aerosols: case study of a Mediterranean industrialized environment, Marseille, Atmos. Chem. Phys., 13, 78757894, doi:10.5194/acp-13-7875-2013, 2013.

Finessi, E., Decesari, S., Paglione, M., Giulianelli, L., Carbone, C., Gilardoni, S., Fuzzi, S., Saarikoski, S., Raatikainen, T., Hillamo, R., Allan, J., Mentel, Th. F., Tiitta, P., Laaksonen, A., Petäjä, T., Kulmala, M., Worsnop, D. R., and Facchini, M. C.: Determination of the biogenic secondary organic aerosol fraction in the boreal forest by NMR spectroscopy, Atmos. Chem. Phys., 12, 941-959, doi:10.5194/acp-12-941-2012, 2012.

Fuzzi, S., Andreae, M. O., Huebert, B. J., Kulmala, M., Bond, T. C., Boy, M., Doherty, S. J., Guenther, A., Kanakidou, M., Kawamura, K., Kerminen, V.-M., Lohmann, U., Russell, L. M., and Pöschl, U.: Critical assessment of the current state of scientific knowledge, terminology, and research needs concerning the role of organic aerosols in the atmosphere, climate, and global change, Atmos. Chem. Phys., 6, 2017-2038, doi:10.5194/acp-62017-2006, 2006.

Gelencsér, A., Mészáros, T., Blazsó, M., Kiss, Gy., Krivácsy, Z., Molnár, A., and Mészáros, E.: Structural Characterisation of Organic Matter in Fine Tropospheric Aerosol by Pyrolysis-Gas Chromatography-Mass Spectrometry, J. Atmos. Chem., 37, 173183, doi:10.1023/A:1006402731340, 2000.

Ghan, S. J. and Schwartz, S. E.: Aerosol properties and processes - A path from field and laboratory measurementsto global climate models, B. Am Meteorol. Soc., 88, 1059-1083, doi:10.1175/BAMS-88-7-1059, 2007.

Graber, E. R. and Rudich, Y.: Atmospheric HULIS: How humic-like are they? A comprehensive and critical review, Atmos. Chem. Phys., 6, 729-753, doi:10.5194/acp-6-729-2006, 2006.

Gustafsson, Ö., Kruså, M., Zencak, Z., Sheesley, R. J., Granat, L., Engström, E., Praveen, P. S., Rao, P. S. P., Leck, C., and Rodhe, H.: Brown Clouds over South Asia: Biomass or Fossil Fuel Combustion?, Science, 323, 495-498, DOI:10.1126/science.1164857, 2009.

Hallquist, M., Wenger, J. C., Baltensperger, U., Rudich, Y., Simpson, D., Claeys, M., Dommen, J., Donahue, N. M., George, C., Goldstein, A. H., Hamilton, J. F., Herrmann, H., Hoffmann, T., Iinuma, Y., Jang, M., Jenkin, M. E., Jimenez, J. L., Kiendler-Scharr, A., Maenhaut, W., McFiggans, G., Mentel, Th. F., Monod, A., Prévôt, A. S. H., Seinfeld, J. H., Surratt, J. D., Szmigielski, R., and Wildt, J.: The formation, properties and impact of secondary organic aerosol: current and emerging issues, Atmos. Chem. Phys., 9, 5155-5236, doi:10.5194/acp-9-51552009, 2009.

Hamburger, T., McMeeking, G., Minikin, A., Birmili, W., Dall'Osto, M., O'Dowd, C., Flentje, H., Henzing, B., Junninen, H., Kristensson, A., de Leeuw, G., Stohl, A., Burkhart, J. F., Coe, H., Krejci, R., and Petzold, A.: Overview of the synoptic and pollution situation over Europe during the EUCAARILONGREX field campaign, Atmos. Chem. Phys., 11, 10651082, doi:10.5194/acp-11-1065-2011, 2011.
Havers, N., Burba, P., Lambertm, J. and Klockow, D.: Spectroscopic characterization of humic-like substances in airborne particulate matter, J. Atmos. Chem., 29, 45-54, 1998.

Hoffer, A., Gelencsér, A., Guyon, P., Kiss, G., Schmid, O., Frank, G. P., Artaxo, P., and Andreae, M. O.: Optical properties of humic-like substances (HULIS) in biomass-burning aerosols, Atmos. Chem. Phys., 6, 3563-3570, doi:10.5194/acp-6-35632006, 2006.

Huffman, J. A., Jayne, J. T., Drewnick, F., Aiken, A. C., Onasch, T., Worsnop, D., and Jimenez-Palacios, J.: Design, Modeling, Optimization, and Experimental Tests of a Particle Beam Width Probe for the Aerodyne Aerosol Mass Spectrometer, Aerosol Sci. Technol., 39, 1143-1163, 2005.

Huffman, J. A., Docherty, K. S., Aiken, A. C., Cubison, M. J., U1brich, I. M., DeCarlo, P. F., Sueper, D., Jayne, J. T., Worsnop, D. R., Ziemann, P. J., and Jimenez, J. L.: Chemically-resolved aerosol volatility measurements from two megacity field studies, Atmos. Chem. Phys., 9, 7161-7182, doi:10.5194/acp-9-71612009, 2009.

IPCC: The Scientific Basis. A report of Working Group I of the Intergovernmental Panel on Climate Change, in: Climate Change 2007: The Physical Science Basis, Contribution of Working Group I to the Fourth Assessment Report of the Intergovernmental Panel on Climate Change, edited by: Solomon, S., Qin, D., Manning, M., Chen, Z., Marquis, M., Averyt, K. B., Tignor M., and Miller, H. L., Cambridge University Press, Cambridge, UK and New York, NY, USA, 2007.

Jaumot, J., Gargallo, R., de Juan, A., and Tauler, R.: A graphical user-friendly interface for MCR-ALS: a new tool for multivariate curve resolution in MATLAB, Chem. Int. Lab. Syst., 76, 101$110,2005$.

Jayne, J. T., Leard, D. C., Zhang, X. F., Davidovits, P., Smith, K. A., Kolb, C. E., and Worsnop, D. R.: Development of an aerosol mass spectrometer for size and composition analysis of submicron particles, Aerosol. Sci. Tech., 33, 49-70, 2000.

Jimenez, J .L., Jayne, J. T., Shi, Q., Kolb, C. E., Worsnop, D. R., Yourshaw, I., Seinfeld, J. H., Flagan, R. C., Zhang, X. F., Smith, K. A., Morris, J. W., and Davidovits, P.: Ambient aerosol sampling using the Aerodyne Aerosol Mass Spectrometer, J. Geophys. Res., 108, 8425, doi:10.1029/2001JD001213, 2003.

Jimenez, J. L., Canagaratna, M. R., Donahue, N. M., Prévôt, A. S. H., Zhang, Q., Kroll, J. H., DeCarlo, P. F., Allan, J. D., Coe, H., Ng, N. L., Aiken, A. C., Docherty, K. S., Ulbrich, I. M., Grieshop, A. P., Robinson, A. L., Duplissy, J., Smith, J. D., Wilson, K. R., Lanz, V. A., Hueglin, C., Sun, Y. L., Tian, J., Laaksonen, A., Raatikainen, T., Rautiainen, J., Vaattovaara, P., Ehn, M., Kulmala, M., Tomlinson, J. M., Collins, D. R., Cubison, M. J., Dunlea, E. J., Huffman, J. A., Onasch, T. B., Alfarra, M. R., Williams, P. I., Bower K., Kondo, Y., Schneider, J., Drewnick, F., Borrmann, S., Weimer, S., Demerjian, K., Salcedo, D., Cottrell, L., Griffin, R., Takami, A., Miyoshi, T., Hatakeyama, S., Shimono, A., Sun J. Y., Zhang, Y. M., Dzepina, K., Kimmel, J. R., Sueper, D., Jayne, J. T., Herndon, S. C., Trimborn, A. M., Williams, L. R., Wood, E. C., Middlebrook, A. M., Kolb, C. E., Baltensperger, U., and Worsnop, D. R.: Evolution of Organic Aerosols in the Atmosphere, Science, 11, 1525-1529, doi:10.1126/science.1180353, 2009.

Kanakidou, M., Seinfeld, J. H., Pandis, S. N., Barnes, I., Dentener, F. J., Facchini, M. C., Van Dingenen, R., Ervens, B., Nenes, A., 
Nielsen, C. J., Swietlicki, E., Putaud, J. P., Balkanski, Y., Fuzzi, S., Horth, J., Moortgat, G. K., Winterhalter, R., Myhre, C. E. L., Tsigaridis, K., Vignati, E., Stephanou, E. G., and Wilson, J.: Organic aerosol and global climate modelling: a review, Atmos. Chem. Phys., 5, 1053-1123, doi:10.5194/acp-5-1053-2005, 2005.

Karakach, T. K., Knight, R., Lenz, E. M., Viant, M. R., and Walter, J. A.: Analysis of time course ${ }^{1} \mathrm{H}$ NMR metabolomics data by multivariate curve resolution, Magn. Reson. Chem., 47 S105$117,2009$.

Kiss, G., Varga, B., Galambos, I., and Ganszky, I.: Characterization of water-soluble organic matter isolated from atmospheric fine aerosol, J. Geophys. Res.-Atmos., 107, D218339, doi:10.1029/2001JD000603, 2002.

Kiss, G., Tombacz, E., Varga, B., Alsberg, T., and Persson, L.: Estimation of the average molecular weight of humic-like substances isolated from fine atmospheric aerosol, Atmos. Environ., 37, 3783-3794, 2003.

Krivácsy, Z., Gelencsér, A., Kiss, G., Meszaros, E., Molnar, A., Hoffer, A., Meszaros, T., Sarvari, Z., Temesi, D., Varga, B., Baltensperger, U., Nyeki, S., and Weingartner, E.: Study on the chemical character of water soluble organic compounds in fine atmospheric aerosol at the Jungfraujoch, J. Atmos. Chem., 39, 235-259, 2001.

Kulmala, M., Asmi, A., Lappalainen, H. K., Carslaw, K. S., Pöschl, U., Baltensperger, U., Hov, Ø., Brenquier, J.-L., Pandis, S. N., Facchini, M. C., Hansson, H.-C., Wiedensohler, A., and O'Dowd, C. D.: Introduction: European Integrated Project on Aerosol Cloud Climate and Air Quality interactions (EUCAARI) - integrating aerosol research from nano to global scales, Atmos. Chem. Phys., 9, 2825-2841, doi:10.5194/acp-92825-2009, 2009.

Kulmala, M., Asmi, A., Lappalainen, H. K., Baltensperger, U., Brenguier, J.-L., Facchini, M. C., Hansson, H.-C., Hov, Ø., O'Dowd, C. D., Pöschl, U., Wiedensohler, A., Boers, R., Boucher, O., de Leeuw, G., Denier van der Gon, H. A. C., Feichter, J., Krejci, R., Laj, P., Lihavainen, H., Lohmann, U., McFiggans, G., Mentel, T., Pilinis, C., Riipinen, I., Schulz, M., Stohl, A., Swietlicki, E., Vignati, E., Alves, C., Amann, M., Ammann, M., Arabas, S., Artaxo, P., Baars, H., Beddows, D. C. S., Bergström, R., Beukes, J. P., Bilde, M., Burkhart, J. F., Canonaco, F., Clegg, S. L., Coe, H., Crumeyrolle, S., D’Anna, B., Decesari, S., Gilardoni, S., Fischer, M., Fjaeraa, A. M., Fountoukis, C., George, C., Gomes, L., Halloran, P., Hamburger, T., Harrison, R. M., Herrmann, H., Hoffmann, T., Hoose, C., Hu, M., Hyvärinen, A., Hõrrak, U., Iinuma, Y., Iversen, T., Josipovic, M., Kanakidou, M., Kiendler-Scharr, A., Kirkevåg, A., Kiss, G., Klimont, Z., Kolmonen, P., Komppula, M., Kristjánsson, J.-E., Laakso, L., Laaksonen, A., Labonnote, L., Lanz, V. A., Lehtinen, K. E. J., Rizzo, L. V., Makkonen, R., Manninen, H. E., McMeeking, G., Merikanto, J., Minikin, A., Mirme, S., Morgan, W. T., Nemitz, E., O’Donnell, D., Panwar, T. S., Pawlowska, H., Petzold, A., Pienaar, J. J., Pio, C., Plass-Duelmer, C., Prévôt, A. S. H., Pryor, S., Reddington, C. L., Roberts, G., Rosenfeld, D., Schwarz, J., Seland, Ø., Sellegri, K., Shen, X. J., Shiraiwa, M., Siebert, H., Sierau, B., Simpson, D., Sun, J. Y., Topping, D., Tunved, P., Vaattovaara, P., Vakkari, V., Veefkind, J. P., Visschedijk, A., Vuollekoski, H., Vuolo, R., Wehner, B., Wildt, J., Woodward, S., Worsnop, D. R., van Zadelhoff, G.-J., Zardini,
A. A., Zhang, K., van Zyl, P. G., Kerminen, V.-M., S Carslaw, K., and Pandis, S. N.: General overview: European Integrated project on Aerosol Cloud Climate and Air Quality interactions (EUCAARI) - integrating aerosol research from nano to global scales, Atmos. Chem. Phys., 11, 13061-13143, doi:10.5194/acp11-13061-2011, 2011.

Langley, L., Leaitch, W. R., Lohmann, U., Shantz, N. C., and Worsnop, D. R.: Contributions from DMS and ship emissions to CCN observed over the summertime North Pacific, Atmos. Chem. Phys., 10, 1287-1314, doi:10.5194/acp-10-1287-2010, 2010.

Lanz, V. A., Alfarra, M. R., Baltensperger, U., Buchmann, B., Hueglin, C., and Prévôt, A. S. H.: Source apportionment of submicron organic aerosols at an urban site by factor analytical modelling of aerosol mass spectra, Atmos. Chem. Phys., 7, 15031522, doi:10.5194/acp-7-1503-2007, 2007.

Lee, D. and Seung, H.: Algorithms for non-negative matrix factorization, Adv. Neural Inform. Process. Syst., 13, 556-562, 2001.

Limbeck, A., Kulmala, M., and Puxbaum, H.: Secondary organic aerosol formation in the atmosphere via heterogeneous reaction of gaseous isoprene on acidic particles, Geophys. Res. Lett., 30, 1996, doi:10.1029/2003GL017738, 2003.

Lin, C.-J.: Projected Gradient methods for Non-negative matrix factorization, Neural Comp., 19, 2756-2779, 2007.

Liu, P., Ziemann, P. J., Kittelson, D. B., and McMurry, P. H.: Generating Particle Beams of Controlled Dimensions and Divergence: II. Experimental Evaluation of Particle Motion in Aerodynamic Lenses and Nozzle Expansions, Aerosol Sci. Technol., 22, 314324, 1995a.

Liu P., Ziemann P.J., Kittelson D.B. and McMurry P.H.: Generating Particle Beams of Controlled Dimensions and Divergence: I. Theory of Particle Motion in Aerodynamic Lenses and Nozzle Expansions, Aerosol Sci. Technol., 22, 293-313, 1995b.

Mancinelli, V., Rinaldi, M., Finessi, E., Emblico, L., Mircea, M., Fuzzi, S., Facchini, M. C., and Decesari, S.: An anion-exchange high-performance liquid chromatography method coupled to total organic carbon determination for the analysis of water-soluble organic aerosols, J. Chromatogr. A., 1149, 385-389, 2007.

Marley, N. A., Gaffney, J. S., Orlandini, K. A., Picel, K. C., and Choppin, G. R.: Chemical characterization of size-fractionated humic and fulvic materials in aqueous samples, Sci. Total Environ., 113, 159-177, 1992.

Mayol-Bracero, O. L., Guyon, P., Graham, B., Roberts, G., Andreae, M. O., Decesari, S., Facchini, M. C., Fuzzi, S., and Artaxo, P.: Water-soluble organic compounds in biomass burning aerosols over Amazonia 2. Apportionment of the chemical composition and importance of the polyacidic fraction, J. Geophys. Res., 107, 8091, doi:10.1029/2001JD000522, 2002.

Mensah, A. A., Holzinger, R., Otjes, R., Trimborn, A., Mentel Th., F., ten Brink, H., Henzing, B., and Kiendler-Scharr, A.: Aerosol chemical composition at Cabauw, The Netherlands as observed in two intensive periods in May 2008 and March 2009, Atmos. Chem. Phys., 12, 4723-4742, doi:10.5194/acp-12-4723-2012, 2012.

Moretti, F., Tagliavini, E., Decesari, S., Facchini, M. C., Rinaldi, M., and Fuzzi, S.: NMR determination of total carbonyls and carboxyls: a tool for tracing the evolution of atmospheric oxidized organic aerosols, Environ. Sci. Technol., 42, 4844-4849, 2008. 
Morgan, W. T., Allan, J. D., Bower, K. N., Esselborn, M., Harris, B., Henzing, J. S., Highwood, E. J., Kiendler-Scharr, A., McMeeking, G. R., Mensah, A. A., Northway, M. J., Osborne, S., Williams, P. I., Krejci, R., and Coe, H.: Enhancement of the aerosol direct radiative effect by semi-volatile aerosol components: airborne measurements in North-Western Europe, Atmos. Chem. Phys., 10, 8151-8171, doi:10.5194/acp-10-81512010, 2010.

Murphy, B. N., Donahue, N. M., Fountoukis, C., Dall'Osto, M., O'Dowd, C., Kiendler-Scharr, A., and Pandis, S. N.: Functionalization and fragmentation during ambient organic aerosol aging: application of the 2-D volatility basis set to field studies, Atmos. Chem. Phys., 12, 10797-10816, doi:10.5194/acp-1210797-2012, 2012.

Ng, N. L., Canagaratna, M. R., Zhang, Q., Jimenez, J. L., Tian, J., Ulbrich, I. M., Kroll, J. H., Docherty, K. S., Chhabra, P. S., Bahreini, R., Murphy, S. M., Seinfeld, J. H., Hildebrandt, L., Donahue, N. M., DeCarlo, P. F., Lanz, V. A., Prévôt, A. S. H., Dinar, E., Rudich, Y., and Worsnop, D. R.: Organic aerosol components observed in Northern Hemispheric datasets from Aerosol Mass Spectrometry, Atmos. Chem. Phys., 10, 46254641, doi:10.5194/acp-10-4625-2010, 2010.

Noziere B., Dziedzic P., and Cordova A.: Products and Kinetics of the Liquid-Phase Reaction of Glyoxal Catalyzed by Ammonium Ions $\left(\mathrm{NH}_{4}^{+}\right)$, J. Phys. Chem. A, 113, 231-237, doi:10.1021/jp8078293, 2009.

Paatero, P.: The Multilinear Engine: A Table-Driven, Least Squares Program for Solving Multilinear Problems, including the $n$-Way Parallel Factor Analysis Model, J. Comp. Graph. Stat., 8, 854888, 1999.

Paatero, P. and Tapper, U.: Analysis of different modes of factor analysis as least squares fit problems, Chemom. Intell. Lab. Syst., 18, 183-194, 1993.

Paatero, P. and Tapper, U.: Positive matrix factorization: A non-negative factor model with optimal utilization of error estimates of data values, Environmetrics, 5, 111-126, doi:10.1002/env.3170050203, 1994.

Petzold, A. and Schönlinner, M.: Multi-angle absorption photometry - a new method for the measurement of aerosol light absorption and atmospheric black carbon, J. Aerosol Sci., 35, 421-441, doi:10.1016/j.jaerosci.2003.09.005, 2004.

Piazzalunga, A., Bernardoni, V., Fermo, P., and Vecchi, R.: Optimisation of analytical procedures for the quantification of ionic and carbonaceous fractions in the atmospheric aerosol and applications to real ambient samples, Anal. Bioanal. Chem., 405, 1123-1132, 2013.

Putaud, J. P., Van Dingenen, R., Alastuey, A., Bauer, H., Birmili, W., Cyrys, J., Flentje, H., Fuzzi, S., Gehrig, R., Hansson, H. C., Harrison, R. M., Herrmann, H., Hitzenberger, R., Hueglin, C., Jones, A. M., Kasper-Giebl, A., Kiss, G., Kousa, A., Kuhlbusch, T. A. J., Loeschau, G., Maenhaut, W., Molnar A., Moreno, T., Pekkanen, J., Perrino, C., Pitz, M., Puxbaum, H., Querol, X., Rodriguez, S., Salma, I., Schwarz, J., Smolik, J., Schneider, J., Spindler, G., ten Brink, H., Tursic, J., Viana, M., Wiedensohler, A., and Raes, F.: A European aerosol phenomenology-3: Physical and chemical characteristics of particulate matter from 60 rural, urban, and kerbside sites across Europe, Atmos. Environ., 44, 1308-1320, doi:10.1016/j.atmosenv.2009.12.011, 2010.
Ravishankara, A. R.: Chemistry-climate coupling: the importance of chemistry in climate issues, Faraday Discuss., 130, 9-26, 2005.

Reinhardt, A., Emmenegger, C., Gerrits, B., Panse, C., Dommen, J., Baltensperger, U., Zenobi, R., and Kalberer, M.: Ultrahigh mass resolution and accurate mass measurements as a tool to characterize oligomers in secondary organic aerosols, Anal. Chem., 79, 4074-4082, 2007.

Rinaldi, M., Emblico, L., Decesari, S., Fuzzi, S., Facchini, M. C., and Librando, V.: Chemical characterization and source apportionment of size-segregated aerosol collected at an urban site in Sicily, Water Air Soil Pollut., 185, 311-321. doi:10.1007/s11270-007-9455-4, 2007.

Roelofs, G.-J. H., ten Brink, H., Kiendler-Scharr, A., de Leeuw, G., Mensah, A., Minikin, A., and Otjes, R.: Evaluation of simulated aerosol properties with the aerosol-climate model ECHAM5HAM using observations from the IMPACT field campaign, Atmos. Chem. Phys., 10, 7709-7722, doi:10.5194/acp-10-77092010, 2010.

Russell, L. M.: Aerosol organic-mass-to-organic-carbon ratio measurements, Environ. Sci. Technol., 37, 2982-2987, 2003.

Russell, L. M., Takahama, S., Liu, S., Hawkins, L. N., Covert, D. S., Quinn, P. K., and Bates, T. S.: Oxygenated fraction and mass of organic aerosol from direct emission and atmospheric processing measured on the R/V Ronald Brown during TEXAQS/GoMACCS 2006, J. Geophys. Res., 114, D00F05, doi:10.1029/2008JD011275, 2009.

Schmidl, C., Bauer, H., Dattler, A., Hitzenberger, R., Weissenboeck, G., Marr, I. L., and Puxbaum, H.: Chemical characterisation of particle emissions from burning leaves, Atmos. Environ., 42, 9070-9079, doi:10.1016/j.atmosenv.2008.09.010, 2008.

Subramanian, R., Khlystov, A. Y., and Robinson, A. L.: Effect of peak inert-mode temperature on elemental carbon measured using thermal-optical analysis, Aerosol Sci. Technol. 40, 763-780, 2006.

Tagliavini, E., Moretti, F., Decesari, S., Facchini, M. C., Fuzzi, S., and Maenhaut, W.: Functional group analysis by $\mathrm{H}$ NMR/chemical derivatization for the characterization of organic aerosol from the SMOCC field campaign, Atmos. Chem. Phys., 6, 1003-1019, doi:10.5194/acp-6-1003-2006, 2006.

Tauler, R.: Multivariate Curve Resolution applied to second order data, Chem. Int. Lab. Syst., 30, 133-146, 1995.

Terrado, M., Barcelo, D., and Tauler, R.: Multivariate curve resolution of organic pollution patterns in the Ebro River surface watergroundwater-sediment-soil system, Anal. Chim. Acta, 657, 1927, doi:10.1016/j.aca.2009.10.026, 2010.

Ulbrich, I. M., Canagaratna, M. R., Zhang, Q., Worsnop, D. R., and Jimenez, J. L.: Interpretation of organic components from Positive Matrix Factorization of aerosol mass spectrometric data, Atmos. Chem. Phys., 9, 2891-2918, doi:10.5194/acp-9-2891-2009, 2009.

Varga, B., Kiss, G., Ganszky, I., Gelencsér, A., and Krivácsy, Z.: Isolation of water-soluble organic matter from atmospheric aerosol, Talanta, 13, 561-572, 2001.

Viana, M., Kuhlbusch T. A. J., Quero,1 X., Alastuey, A., Harrison, R. M., Hopke, P. K., Winiwarter, W., Vallius, M., Szidat, S., Prévôt, A. S. H., Hueglin, C., Bloemen, H., Wåhlin, P., Vecchi, R., Miranda, A. I., Kasper-Giebl, A., Maenhaut, W., and Hitzenberger, 
R.: Source apportionment of particulate matter in Europe: a review of methods and results, J. Aerosol Sci., 39, 827-849, 2008.

Volkamer, R., Jimenez, J. L., San Martini, F., Dzepina, K., Zhang, Q., Salcedo, D., Molina, L. T., Worsnop, D. R., and Molina, M. J.: Secondary organic aerosol formation from anthropogenic air pollution: Rapid and higher than expected, Geophys. Res. Lett., 33, L17811, doi:10.1029/2006GL026899, 2006.

Wentzell, P. D., Karakach, T. K., Roy, S., Martinez, M. J., Allen, C. P., and Werner-Washburne, M.: Multivariate curve resolution of time course microarray data, BMC Bioinformatics 7, 343-362, 2006.

Zhang, Q., Alfarra, M. R., Worsnop, D. R., Allan, J. D., Coe, H., Canagaratna, M. R., and Jimenez, J. L.: Deconvolution and quantification of hydrocarbon-like and oxygenated organic aerosols based on aerosol mass spectrometry, Environ. Sci. Technol., 39, 4938-4952, 2005.

Zhang, Q., Jimenez, J. L., Canagaratna, M., Allan, J., Coe, H., Ulbrich, I., Alfarra, M., Takami, A., Middlebrook, A., Sun, Y., Dzepina, K., Dunlea, E., Docherty, K., De-Carlo, P., Salcedo, D., Onasch, T., Jayne, J., Miyoshi T., Shimono, A., Hatakeyama, S., Takegawa, N., Kondo, Y., Schneider J., Drewnick F., Borrmann, S., Weimer, S., Demerjian, K., Williams, P., Bower K., Bahreini, R., Cottrell, L., Griffin, R., Rautiainen, J., Sun, J., Zhang, Y., and Worsnop, D.: Ubiquity and dominance of oxygenated species in organic aerosols in anthropogenically influenced Northern Hemisphere midlatitudes, Geophys. Res. Lett., 34, L13801, doi:10.1029/2007GL029979, 2007.
Zhang, Q., Jimenez, J. L., Canagaratna, M. R., Ulbrich, I. M., Ng, S. N., Worsnop D. R., and Sun, Y.: Understanding Atmospheric Organic Aerosols via Factor Analysis of Aerosol Mass Spectrometry: a Review, Anal. Bioanal. Chem., 401, 3045-3067, doi:10.1007/s00216-011-5355-y, 2011.

Zhang, X., Smith, K. A., Worsnop, D. R., Jimenez, J. L., Jayne, J. T., Kolb, C. E., Morris, J., and Davidovits, P.: Numerical Characterization of Particle Beam Collimation: Part II Integrated Aerodynamic-Lens-Nozzle System, Aerosol Sci. Technol., 38, 619-638, 2004. 